\title{
High-resolution neodymium characterization along the Mediterranean margins and modelling of $\varepsilon_{\mathrm{Nd}}$ distribution in the Mediterranean basins
}

\author{
Mohamed Ayache $^{1}$, Jean-Claude Dutay ${ }^{1}$, Thomas Arsouze ${ }^{2,3}$, Sidonie Révillon ${ }^{4}$, Jonathan Beuvier ${ }^{5,6}$, and \\ Catherine Jeandel ${ }^{7}$ \\ ${ }^{1}$ Laboratoire des Sciences du Climat et de l'Environnement LSCE/IPSL, CEA-CNRS-UVSQ, Université Paris-Saclay, \\ 91191 Gif-sur-Yvette, France \\ ${ }^{2}$ ENSTA ParisTech, Université Paris-Saclay, 828 bd des Maréchaux, 91762 Palaiseau CEDEX, France \\ ${ }^{3}$ Laboratoire de Météorologie Dynamique, École Polytechnique, Palaiseau, France \\ ${ }^{4}$ SEDISOR/UMR6538 “Laboratoire Domaines Océaniques”, IUEM, CNRS-UBO, Plouzané, France \\ ${ }^{5}$ Mercator-Océan, Ramonville Saint-Agne, France \\ ${ }^{6}$ Météo-France, Toulouse, France \\ ${ }^{7}$ LEGOS, Université de Toulouse, CNRS, CNES, IRD, UPS, Toulouse, France
}

Correspondence to: Mohamed Ayache (mohamed.ayache@1sce.ipsl.fr)

Received: 24 March 2016 - Published in Biogeosciences Discuss.: 5 April 2016

Revised: 12 August 2016 - Accepted: 8 September 2016 - Published: 22 September 2016

\begin{abstract}
An extensive compilation of published neodymium $(\mathrm{Nd})$ concentrations and isotopic compositions (Nd IC) was realized in order to establish a new database and a map (using a high-resolution geological map of the area) of the distribution of these parameters for all the Mediterranean margins. Data were extracted from different kinds of samples: river solid discharge deposited on the shelf, sedimentary material collected on the margin or geological material outcropping above or close to a margin. Additional analyses of surface sediments were done in order to improve this data set in key areas (e.g. Sicilian strait).

The Mediterranean margin $\mathrm{Nd}$ isotopic signatures vary from non-radiogenic values around the Gulf of Lion, $\left(\varepsilon_{\mathrm{Nd}}\right.$ values $\sim-11$ ) to radiogenic values around the Aegean and the Levantine sub-basins up to +6 . Using a high-resolution regional oceanic model $\left(1 / 12^{\circ}\right.$ of horizontal-resolution), $\varepsilon_{\mathrm{Nd}}$ distribution was simulated for the first time in the Mediterranean Sea.

The high resolution of the model provides a unique opportunity to represent a realistic thermohaline circulation in the basin and thus apprehend the processes governing the $\mathrm{Nd}$ isotope distribution in the marine environment. Results are consistent with the preceding conclusions on boundary ex-
\end{abstract}

change (BE) as an important process in the Nd oceanic cycle. Nevertheless this approach simulates a too-radiogenic value in the Mediterranean Sea; this bias will likely be corrected once the dust and river inputs will be included in the model.

This work highlights that a significant interannual variability of $\varepsilon_{\mathrm{Nd}}$ distribution in seawater could occur. In particular, important hydrological events such as the Eastern Mediterranean Transient (EMT), associated with deep water formed in the Aegean sub-basin, could induce a shift in $\varepsilon_{\mathrm{Nd}}$ at deep/intermediate depths that could be noticeable in the eastern part of the basin. This underlines that the temporal and geographical variations of $\varepsilon_{\mathrm{Nd}}$ could represent an interesting insight of $\mathrm{Nd}$ as tracer of the Mediterranean Sea circulation, in particular in the context of palaeo-oceanographic applications.

\section{Introduction}

The Mediterranean Sea is a semi-enclosed sea of great interest because it is submitted to large range of dynamical processes and interactions, such as strong air-sea exchanges leading to open-sea deep-water convection feeding a 
thermohaline circulation cell (Malanotte-Rizzoli and Robinson, 1988), strait transports and dynamics or cross-shore exchanges. From a biogeochemical perspective, it is a region receiving the highest aerosol loads owing to air masses carrying numerous and various aerosol types (Lelieveld et al., 2002; Nabat et al., 2014), where oligotrophy occurs and with a characteristic dynamic of the deep chlorophyll maximum (Mignot et al., 2014). Under the stress of the global change and anthropogenic forcing, understanding the functioning of the Mediterranean Sea and quantifying the biogeochemical cycles is a priority (MerMex-Group, 2011).

Neodymium (Nd) is a Rare Earth Element (REE) with seven naturally occurring isotopes. The radiogenic isotope ${ }^{143} \mathrm{Nd}$ is produced by the radioactive $\alpha$-decay of ${ }^{147} \mathrm{Sm}$. At the continent surface, the $\mathrm{Nd}$ isotopic composition (usually expressed as $\varepsilon_{\mathrm{Nd}}{ }^{1}$ of a given material) is a function of the $\mathrm{Sm} / \mathrm{Nd}$ ratio characterizing this material, which is primarily a function of its age and lithology. On a global scale, it is higher in the Earth's mantle compared to its crust. As a consequence, the $\varepsilon_{\mathrm{Nd}}$ of the continents presents a heterogeneous distribution (Goldstein and Hemming, 2003; Jeandel et al., 2007).

$\mathrm{Nd}$ residence time ranges from 700 to 1500 years in the global ocean (e.g. Lacan et al., 2012), long enough to be transported within the global thermohaline circulation system and short enough to avoid complete homogenization. Therefore, $\varepsilon_{\mathrm{Nd}}$ is often considered to be a "quasiconservative" tracer. In other words, $\varepsilon_{\mathrm{Nd}}$ values of the water masses could be conserved up to long distances from the source of lithogenic inputs. In such a context, it could be used to tag water masses with distinct isotopic compositions in order to constrain water mass mixing and pathways, as well as the thermohaline circulation in modern and palaeo ocean circulation (e.g. Lacan and Jeandel, 2005; Jeandel, 1993; Jeandel et al., 1998; Frank, 2002; Goldstein and Hemming, 2003; Piotrowski et al., 2004, 2012; Stichel et al., 2012; Martin et al., 2012; Pena et al., 2013; Molina-Kescher et al., 2014; Arsouze et al., 2008). However, because Nd is particle reactive, $\mathrm{Nd}$ parameters are also successfully used to study $\mathrm{Nd}$ exchange between dissolved and particulate phases (Bertram and Elderfield, 1993; Henry et al., 1994; Jeandel et al., 1995; Tachikawa et al., 1999, 2003; Garcia-Solsona et al., 2014; Rousseau et al., 2015; Haley et al., 2014).

$\mathrm{Nd}$ sources to the ocean are lithogenic, and the mean $\varepsilon_{\mathrm{Nd}}$ of an oceanic basin is representative of the surrounding continents (Jeandel et al., 2007). During the last few years, significant progress has been made in understanding how different water masses acquire their Nd IC (Isotopic Composition). In the early 2000s, Tachikawa et al. (2003) and Lacan and Jeandel (2005) suggested that exchange of Nd between the sediments deposited on the oceanic margins and

\footnotetext{
${ }^{1} \varepsilon_{\mathrm{Nd}}=\left[\left({ }^{143} \mathrm{Nd} /{ }^{144} \mathrm{Nd}\right)_{\mathrm{sample}} /\left({ }^{143} \mathrm{Nd} /{ }^{144} \mathrm{Nd}\right)_{\mathrm{CHUR}}-1\right] \times 10^{4}$, where $\left({ }^{143} \mathrm{Nd} /{ }^{144} \mathrm{Nd}\right)_{\mathrm{CHUR}}=0512638$ is the averaged earth value (Jacobsen and Wasserburg, 1980).
}

the waters flowing along these margins, called the "boundary exchange" (BE) was the missing Nd source that could balance both the concentration and isotopic distributions of $\mathrm{Nd}$ on regional and world scales. Since these pioneer works, many studies have confirmed this hypothesis (Rickli et al., 2009, 2010; Stichel et al., 2012; Wilson et al., 2012; Grenier et al., 2013; Carter et al., 2012). The modelling studies have reached the same conclusions on the relative importance of the BE on the Nd oceanic cycle on the global scale, although dust and river inputs could locally affect the surface waters, such as off the Sahara.(Arsouze et al., 2007; Siddall et al., 2008; Arsouze et al., 2009; Rempfer et al., 2011).

The Nd influx brought by the Atlantic inflow in the Strait of Gibraltar is smaller than the $\mathrm{Nd}$ outflux exiting with the Mediterranean outflow (Tachikawa et al., 2004; Greaves et al., 1991; Henry et al., 1994). The $\varepsilon_{\mathrm{Nd}}$ value of the Mediterranean outflow was estimated to be -9.4 (Henry et al., 1994; Tachikawa et al., 2004), which is higher than that of the Atlantic inflow $\left(\varepsilon_{\mathrm{Nd}}=-11.8\right.$; Spivack and Wasserburg, 1988). Thus, a source of radiogenic $\mathrm{Nd}$ is required to balance these fluxes.

Frost et al. (1986) and Spivack and Wasserburg (1988) proposed that the additional $\mathrm{Nd}$ source might be the partial dissolution of river particles and/or aeolian particles. Greaves et al. (1991) argued that the missing source might rather be of marine origin. Schijf et al. (1991) suggested that the Black Sea was a net source to the Mediterranean Sea. Based on a two-box model Henry et al. (1994) suggested that the $\varepsilon_{\mathrm{Nd}}$ in the Ligurian sub-basin deep waters required an exchange involving $30 \pm 20 \%$ of the sinking particles of atmospheric origin. Finally, Tachikawa et al. (2004) proposed that the missing term could be sediments deposited on the margins. In other words, the origin of this radiogenic input remains unclear. The present study aims to compile data and develop modelling tools for clarifying this issue.

The circulation of the Mediterranean Sea is driven by the fact that the mean evaporation exceeds the mean precipitation, leading to a density increase along surface water mass paths and subsequent strong convective events in winter. The main deep-water sources are located in the Gulf of Lion (south of France) for the western Mediterranean Sea (WMed), and the Adriatic sub-basin for the eastern Mediterranean Sea (EMed; Millot and Taupier-Letage, 2005). In the mid-1990s a shift in the deep-water formation site occurred during the Eastern Mediterranean Transient (EMT) events. The EMT describes a temporary change in the Eastern Mediterranean Deep Water (EMDW) formation site that switched from the Adriatic to the Aegean sub-basin (Roether et al., 1996, 2007; Lascaratos et al., 1999; Malanotte-Rizzoli et al., 1999; Theocharis et al., 1992, 1999). The new source has produced large quantities of very dense water masses, in particular the Cretan Deep Water (CDW) that overflowed through the Cretan Arc straits and subsequently filled the eastern Mediterranean with waters denser than the previously existing deep and bottom wa- 


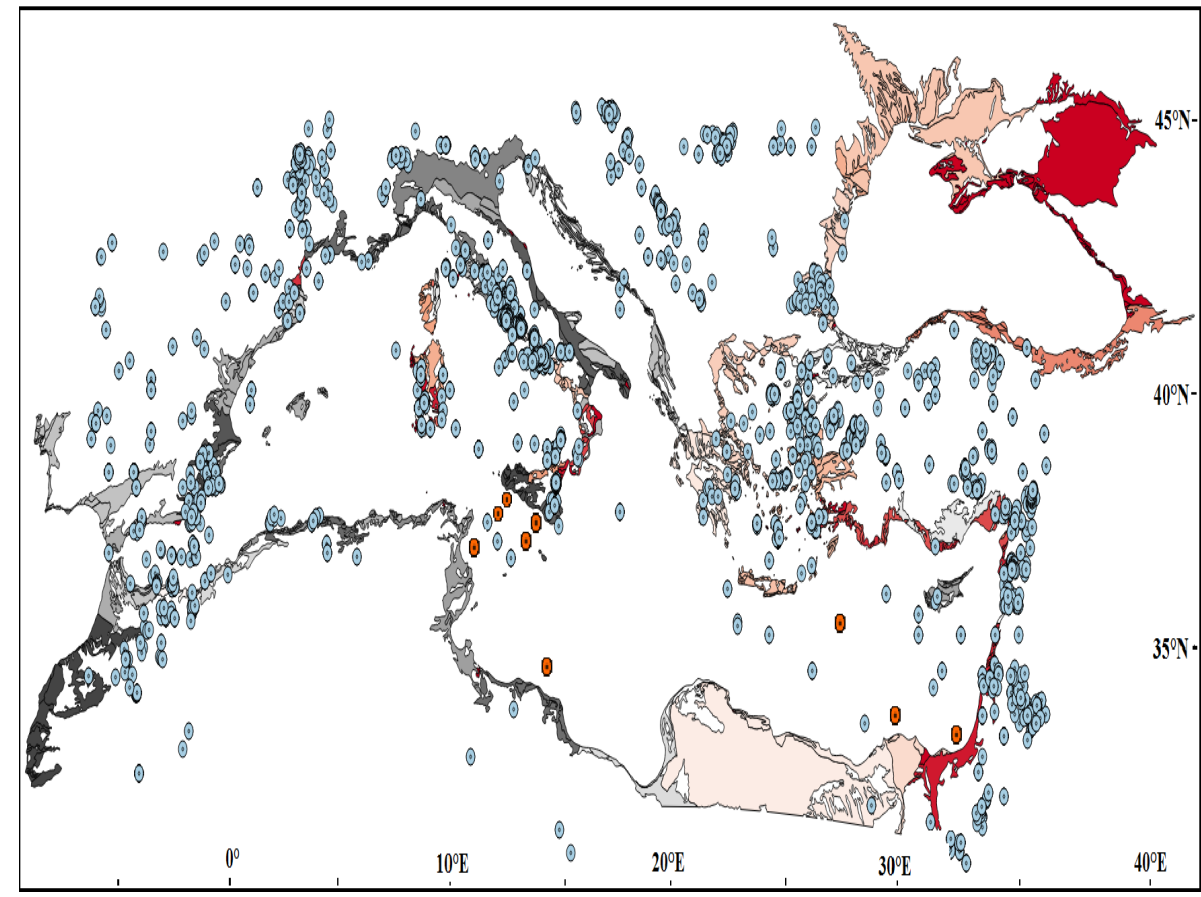

Figure 1. The filled contours indicate the geological province limit based on geological age (i.e. each colour represents an age) from a highresolution digital geological map (http://www.geologie.ens.fr/spiplabocnrs/spip.php?rubrique67) while the circles filled in blue represent the location of the discrete data compiled from the EarthChem database (see Supplement 1), and in red the location of the stations correspond to the sediments analysed as part of the present work.

ter. However, EMT was revealed using hydrographic and anthropogenic tracers such as $\mathrm{CFC}$ and ${ }^{3} \mathrm{H}$. Both are transients and are not imprinted in the sediments. Establishing the occurrence of a similar EMT event in the past would require the identification of proxies that clearly identify the distribution and circulation of the different water masses, which is memorized in the sediments.

Tachikawa et al. (2004) demonstrated that the Nd isotopic signature is more conservative than the salinity in the Mediterranean Sea, the latter being strongly affected by the evaporation. In addition, these authors revealed that the Mediterranean water masses are well distinguished by their $\mathrm{Nd}$ isotopic signatures. The Mediterranean Sea makes an excellent "laboratory test" basin for studying the potential $\varepsilon_{\mathrm{Nd}}$ distribution variations as it is a semi-enclosed basin with a quite short residence time of the waters (50-100 years; Millot and Taupier-Letage, 2005). This paper also aims to investigate how EMT events affect the $\mathrm{Nd}$ distribution in the Mediterranean basin in order to estimate the potential of this tracer to characterize from palaeo archive (e.g. corals, foraminifera) the occurrence of such event in the past. Modelling represents an appropriate tool to address this question.

In this study, we developed a new modelling platform for simulating Nd isotopic composition at high resolution in the Mediterranean basin.

First, the results of a dense compilation of the concentrations and isotopic compositions of the different materials that constitute the Mediterranean margins, which are expected to interact with the water masses, are presented. This highresolution mapping was established using a detailed geological map, providing the most realistic representation of the Mediterranean geology existing so far (see Figs. 1 and 2, and Supplement 1).

The approach by Arsouze et al. (2007) to simulate the BE was evaluated and generally accepted by the scientific community (e.g. Arsouze et al., 2009), following this protocol made up for the global scale, we implemented the neodymium in a high-resolution regional model (NEMOMED12) developed for the Mediterranean Sea. We used dissolved $\varepsilon_{\mathrm{Nd}}$ data compiled by Tachikawa et al. (2004), Vance et al. (2004), Henry et al. (1994) to evaluate the ability of this model to reproduce the main features of the circulation and mixing of the Mediterranean Sea water masses for which $\mathrm{Nd}$ signatures are known. These tools provided perspectives on (i) the $\varepsilon_{\mathrm{Nd}}$ distribution in the whole Mediterranean Sea, (ii) the impact of the interannual variability of the thermohaline circulation (e.g. EMT event) on the modelled $\varepsilon_{\mathrm{Nd}}$ distribution, and (iii) high resolution of the geological field on the one hand and the model on the other hand can reveal possible local heterogeneities which could reflect local BE effects.

This study is part of the work carried out to assess the robustness of the NEMO-MED12 model, used to study the thermohaline circulation and the biogeochemical cycles in the Mediterranean Sea, and it improves our ability to predict 


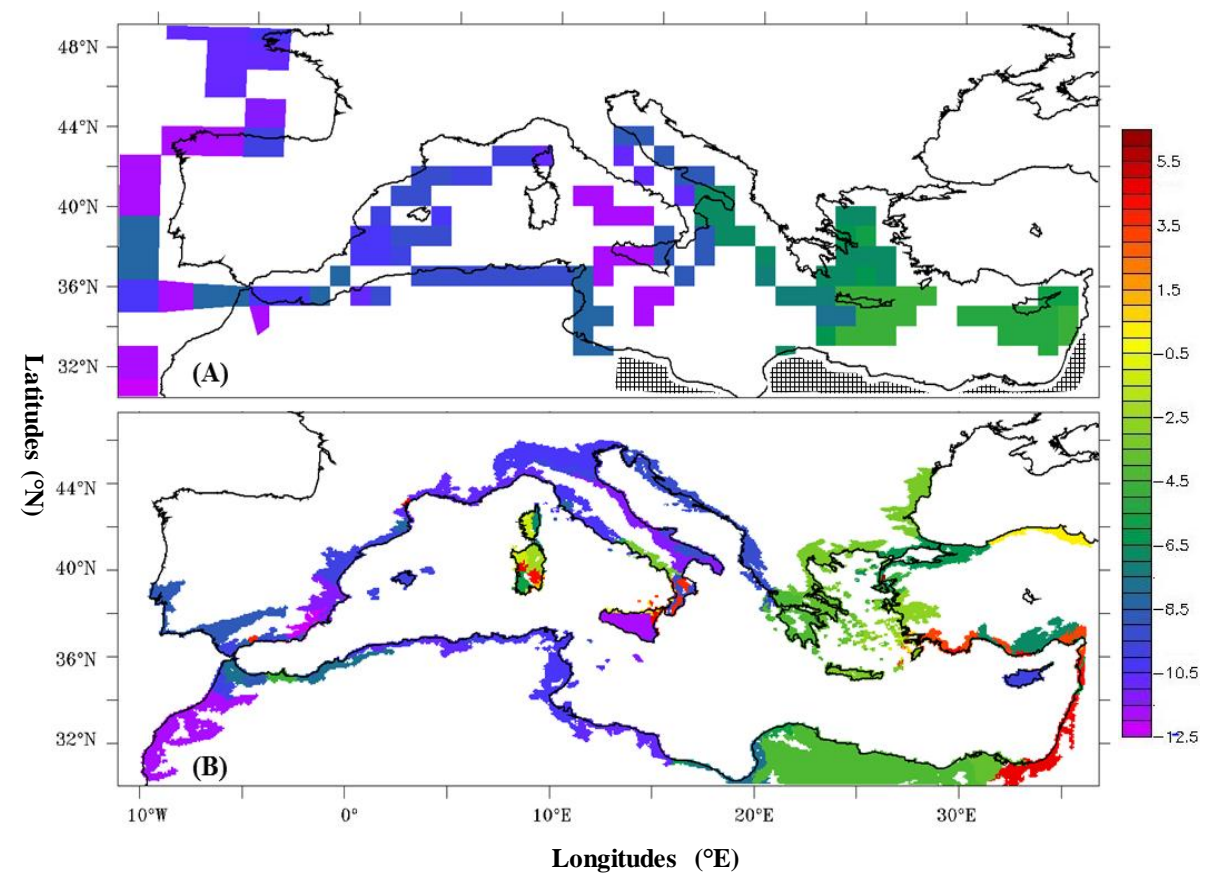

Figure 2. Extrapolated map providing a picture of the Nd signature of all the margins surrounding the Mediterranean Sea. (a) Low-resolution configuration ORCA2 (reproduced from Jeandel et al., 2007) and (b) high-resolution configuration NEMO-MED12 (this work). Hatched areas correspond to uncharacterized areas in the published literature (before 2007) as done by Jeandel et al. (2007).

the future evolution of this basin under increasing anthropogenic pressure (Drobinski et al., 2012).

\section{Data compilation and representation on the Mediterranean margins}

Here we present the data compilation procedure and resulting map (Fig. 2) allowing us to characterize the Nd isotopic signatures and concentrations of all the margins surrounding the Mediterranean Sea.

Our approach was to prioritize the use of data directly measured in the outcropping sediments or geological fields, as proposed by Jeandel et al. (2007). An extensive compilation of all published $\mathrm{Nd}$ concentrations and isotopic values was made using the EarthChem database (http://www. earthchem.org) with a zoomed-in image of the Mediterranean region (latitude between 28 to $48^{\circ} \mathrm{N}$, and between $10^{\circ} \mathrm{W}$ and $40^{\circ} \mathrm{E}$ in longitude). This yielded assets of more than 14200 discrete data reported in Supplement 1 and located in Fig. 1. When data were missing in crucial areas (e.g. Strait of Sicily), we directly measured them on core-top sediments.

Finally, we used a high-resolution numerical geological map to interpolate/extrapolate data from similar geological areas. Below we briefly discuss the pros and cons of this latter approach.

\subsection{Sediment core tops and erodible material data}

Surface sediments collected on the shelf or the slope were our first choice because they provide direct information on the geochemical and isotopic characteristics of the material in contact with the water masses. Sediments deposited during the recent Holocene were taken into consideration. When surface sediment data were missing, we took into account the $\mathrm{Nd}$ parameters of erodible material deposited along the coasts (Jeandel et al., 2007). The EarthChem database provides a good spatial covering in the northern coastline (Fig. 1), in contrast to the southern coastline (e.g. Algerian coast), while there are no published data for the Tunisian, Libyan and Egyptian coasts. We therefore distinguished between the two cases Sects. 2.1.1 and 2.1.2.

\subsubsection{Areas with high spatial resolution of available data}

For this kind of region (i.e. Italian coast) and for each geological province, we carefully established the extent to which we could extrapolate the measured values to the whole province. The average $\varepsilon_{\mathrm{Nd}}$ values for each geological province were calculated, taking into account the number of cores collected in a given area, and the geochemical characteristics of the analysed sediments. We neglected data for specific areas like very small volcanoes which were not representative of the geochemical and isotopic characteristics of the region, such as in the Strait of Sicily (see Supplement 1 reports the full 
treatment, results and uncertainties). This approach was to generate relatively robust $\mathrm{Nd}$ isotopic signatures characterizing the whole of the northern Mediterranean Sea margins, with a standard deviation less than $2 \varepsilon_{\mathrm{Nd}}$ units in most cases.

\subsubsection{Areas with low spatial resolution of available data}

For the southern coast, we gathered sediment samples from miscellaneous origins. Those were collected during the cruises of ETNA80, DEDALE and NOE near the Tunisian, Libyan and the Egyptian coasts respectively (see Table 1). In the Strait of Sicily samples were collected along two transects, Sciacca-Pantelleria (SP) and Pozzallo-Malta (PM), perpendicular to the southern coast of Sicily (Tranchida et al., 2011). The sampling site identifications, depths, collection dates and positions are compiled in Table 1.

Sediment samples were analysed for $\mathrm{Nd}$ radiogenic isotopes. About $100 \mathrm{mg}$ of samples were weighted and dissolved in teflon beakers in a mixture of ultrapure quartex $\mathrm{HF}(24 \mathrm{~N}), \mathrm{HNO}_{3}(14 \mathrm{~N})$ and $\mathrm{HClO}_{4}(12 \mathrm{~N})$ for 4 days at $160{ }^{\circ} \mathrm{C}$ on a hot plate. After evaporation to dryness samples were dissolved in aqua regia and heated for $24 \mathrm{~h}$ at $130{ }^{\circ} \mathrm{C}$. Nd fractions were chemically separated following conventional column chemistry procedures described in Révillon et al. (2011). Nd isotope compositions were measured in static mode on a Thermo TRITON at the PSO (Pole de Spectrométrie Océan) in Brest, France. All measured Nd ratios were normalized to ${ }^{146} \mathrm{Nd} /{ }^{144} \mathrm{Nd}=0.7219$. During the course of analysis, $\mathrm{Nd}$ standard solution La Jolla gave $0.511854 \pm 0.000008(2 \alpha ; n=28$, recommended value 0.511850$)$ and JNdi gave $0.512099 \pm 0.000010(2 \alpha$; $n=6$, recommended value 0.512100 ). Procedural blanks were all below $200 \mathrm{pg}$ and therefore negligible in all cases.

\subsection{River and dust inputs}

Dissolved Nd in river water is efficiently removed from solution by coagulation of colloids during the estuarine mixing. The recent compilation of Rousseau et al. (2015) confirmed that on a global scale $71.8 \pm 16 \%$ of dissolved riverine $\mathrm{Nd}$ is removed by this process, in agreement with preceding works (e.g. Elderfield et al., 1990). In addition, these authors evidenced that lithogenic $\mathrm{Nd}$ is released at higher salinities by the suspended particulate material discharged by the river. Globally, this could represent $5700 \pm 2600 \mathrm{Mg}$ of dissolved $\mathrm{Nd}$ annually brought to the ocean by this mechanism, a flux 6-17 times larger than the dissolved one, and 8 to 21 times larger than the atmospheric flux, assuming $2 \%$ dust dissolution. Note that the mechanism evidenced in the Amazon estuary by Rousseau et al. (2015) does not describe all the processes likely to affect the sediments deposited on the shelves and margins. The hypothesis was modelled by Arsouze et al. (2009) and Rempfer et al. (2011). Dust input is also difficult to constrain: while flux is sporadic and hard to characterize,
Table 1. Coordinates of the studied cores together with water depth.

\begin{tabular}{llllrr}
\hline Cruise & Years & $\begin{array}{l}\text { Longitude } \\
\left({ }^{\circ} \mathrm{E}\right)\end{array}$ & $\begin{array}{c}\text { Latitude } \\
\left({ }^{\circ} \mathrm{N}\right)\end{array}$ & $\begin{array}{r}\text { Depth } \\
(\mathrm{m})\end{array}$ & $\varepsilon_{\mathrm{Nd}}$ \\
\hline \multirow{2}{*}{ ETNA80 } & \multirow{2}{*}{1980} & 11.48 & 36.30 & 263 & -10.09 \\
& 13.44 & 33,23 & 736 & -10.92 \\
\hline \multirow{2}{*}{ DEDALE } & \multirow{2}{*}{1987} & 25.59 & 33.51 & 3020 & -8.15 \\
\hline \multirow{2}{*}{ NOE } & \multirow{2}{*}{1984} & 30.01 & 32.19 & 1465 & -4.49 \\
& & 30.1 & 31.53 & 495 & -3.92 \\
\hline \multirow{3}{*}{ Strait of Sicily } & \multirow{2}{*}{2003} & 12.57 & 37.30 & 29.5 & -11.67 \\
& & 14.37 & 36.36 & 87.4 & -11.05 \\
& & 12.32 & 36.16 & 488.2 & -11.22 \\
& & & 36.56 & 117 & -8.06 \\
\hline
\end{tabular}

establishing the fraction dissolved at the air-sea interface is also challenging.

The main river systems of the Mediterranean basin are the Nile, Po and Rhone. River plume extensions were established using maps and satellite images from data banks provided by Ludwig et al. (2009).

$\mathrm{Nd}$ input derived from the Nile river water and/or particles could be transported eastward and northward to the Rhodes Gyre where the LIW is formed. Tachikawa et al. (2004) suggest that the most significant radiogenic $\mathrm{Nd}$ source to the EMed is partially dissolved Nile River particles, radiogenic $\mathrm{Nd}$ supplies to the eastern basin being formed by dissolved and particulate loads ( $\varepsilon_{\mathrm{Nd}}$ of about $\left.\sim-4\right)$.

Henry et al. (1994) have studied the potential impact of river inputs on the $\mathrm{Nd}$ isotopic composition of the WMed. The Rhone transports $80 \%$ of the solid riverine discharge into the north-western Mediterranean Sea (Leveau and Coste, 1987). According to Henry et al. (1994) the Rhone dissolved water and superficial sediments display an average $\varepsilon_{\mathrm{Nd}}$ value of $-10.2 \pm 0.5$.

In contrast, the Po river is less documented. The geographical extension of Po river drainage basin was defined using the digital geological map referenced above, and Ludwig et al. (2009) database. These information allowed us to extract the $\mathrm{Nd}$ isotopic signatures from the work of Conticelli et al. (2009), Prelević et al. (2008) and Owen (2007). These studies are the most representative of the Po drainage basin so far.

Finally, we included aeolian inputs in our compilation. To this extent, the review of Scheuvens et al. (2013) was of great help. Indeed, this work presents a review of bulk composition data of northern dust inputs, their potential sediment sources and their elemental, isotope and mineralogical characteristics. Actually, these aeolian data will not be immediately used in our modelling approach. However, we considered relevant to present them with the remaining data, which allowed us to propose the most comprehensive data set.

All the discrete data extracted from the literature are reported in Supplement 1 and Fig. 1. 


\subsection{Extrapolation and extrapolation}

Extrapolating the collected discrete data is required to allocate the margins with continuous $\mathrm{Nd}$ concentration and isotopic compositions. In other words, we attribute an isotopic signature and $\mathrm{Nd}$ concentration to any margin area liable to be in contact with the waters flowing through. To this end, the tools developed by Jeandel et al. (2007) for the world margins were adapted for the Mediterranean Sea.

Because the $\mathrm{Nd}$ isotopic composition of any field is closely related to its geological nature and age (O'Nions et al., 1979; Goldstein et al., 1984, 1997; Allegre, 2005) we used a high-resolution digital geological map which provides the contours of the fields (Fig. 1) of a given geological age and type (http://www.geologie.ens.fr/spiplabocnrs/spip.php? rubrique67). This allowed us to estimate the size of the coastal segments that could provide material with the same $\mathrm{Nd}$ characteristics.

In poorly documented areas, we first considered the age and geochemical nature of the field (Jeandel et al., 2007). Then we applied the same isotopic signature as similar fields of the same age based on the Nd model-age relationships (Allegre, 2005; Goldstein et al., 1984, 1997; O’Nions et al., 1979). This was thoroughly done by checking the geology, geochemistry and $\mathrm{Nd}$ signatures of the fields identified as the source of deposited material. Note that the resolution of the available data in the Mediterranean basin is relatively high, reducing the uncertainties of the approach described above (see Sect. 2, Supplement 1), Fig. $2 \mathrm{~b}$ reveals the improvement allowed by this approach by comparing the highresolution patchwork of field documented to an extraction of the Mediterranean Sea basin (Fig. 2a) from the global lowresolution distribution of Jeandel et al. (2007) (see Sect. 4.1).

\section{Modelling the Nd isotopic composition}

\subsection{Description of the model}

We use the free-surface ocean circulation model NEMO (Nucleus for European Modelling of the Ocean) (Madec and NEMO-Team., 2008) in a regional configuration called NEMO-MED12 (Beuvier et al., 2012a), already used for biogeochemical studies (Ayache et al., 2015a, b; Guyennon et al., 2015; Palmiéri et al., 2015). This model uses the standard ORCA grid of NEMO at $1 / 12^{\circ}$ resolution. This corresponds to a grid cell size in the Mediterranean area varying with latitude between 6 and $8 \mathrm{~km}$, from 46 to $30^{\circ} \mathrm{N}$ and it extends into the Atlantic Ocean to $11^{\circ} \mathrm{W}$ (buffer zone). Vertical resolution varies with depth from $\Delta Z=1 \mathrm{~m}$ at the surface to $\Delta Z=450 \mathrm{~m}$ at the bottom with 35 levels in the first $1000 \mathrm{~m}$ (50 levels in total).

Daily mean fields of momentum, freshwater flux (evaporation minus precipitation) and net heat flux from the highresolution atmospheric data set (ARPERA) are used for the air-sea fluxes (Herrmann and Somot, 2008; Herrmann et al., 2010). The heat flux is applied with a retroaction term using the ERA-40 sea surface temperature (SST).

The initial state (temperature, salinity) for the Mediterranean Sea came from the MedAtlas-II (Rixen et al., 2005; MEDAR-MedAtlas-group, 2002) climatology weighted by a low-pass filter with a time window of 10 years using the MedAtlas data covering the 1955-1965 period, following Beuvier et al. (2012b). For the temperature and salinity in the buffer zone (west of the Strait of Gibraltar), the initial state is prescribed from the 2005 World Ocean Atlas (Antonov et al., 2006; Locarnini et al., 2006). River run-off is prescribed from the interannual data set of Ludwig et al. (2009). The Black Sea is not explicitly included in the models, but is rather treated as one of the major freshwater sources of the Mediterranean Sea located at the Dardanelles strait, with a flux corresponding to the Dardanelles net budget estimates of Stanev and Peneva (2002).

NEMO-MED12 model simulates the main features of the thermohaline circulation and mixing of the Mediterranean Sea water masses and their interannual variability. In particular, the propagation of the Levantine Intermediate Water (LIW) from the eastern to the western basin is produced with realistic timescale compared to the observations (Ayache et al., 2015a). However, some aspects of the model still need to be improved. For example, the formation of Adriatic Deep Water (AdDW) is too weak, leading to a too-low contribution to the EMDW in the Ionian sub-basin (Palmiéri et al., 2015; Ayache et al., 2015a, b). The atmospheric forcing used by Beuvier et al. (2012b) includes some modifications to improve dense water fluxes through the Cretan Arc during the EMT. As established in the previous version of NEMO-MED8 (1/8 ${ }^{\circ}$ of horizontal resolution, Beuvier et al., 2010), the model is able to reproduce a transient deep-water formation as observed for the EMT, but the simulated transient produced less Eastern Mediterranean Deep Water (EMDW). Beuvier et al. (2012b) later performed a sensitivity test with modified forcing. The ARPERA forcings were modified over the Aegean sub-basin, by increasing daily water loss by $1.5 \mathrm{~mm}$, daily surface heat loss by $40 \mathrm{~W} \mathrm{~m}^{-2}$, and the daily wind stress modulus by $0.02 \mathrm{~N} \mathrm{~m}^{-2}$ during November to March in the winters of 1991-1992 and 1992-1993, as done by Herrmann and Somot (2008) to study deep convection in the Gulf of Lion. This resulted in average wintertime increases in heat loss $(+18 \%)$, water loss $(+41 \%)$ and wind intensity $(+17 \%)$ over the Aegean subbasin. These changes generate an improved circulation that satisfyingly reproduced the formation and renewal of the deep water in the eastern basin during the EMT event (Ayache et al., 2015a). These performances of the dynamical model have to be kept in mind when analysing the Nd simulations. 


\subsection{The tracer model}

Using different modelling approaches, Arsouze et al. (2007, 2010) and Rempfer et al. (2011) have shown that the exchange between the continental margins and seawater, the boundary exchange (BE) represents the major source of $\mathrm{Nd}$ on the global scale. This source represents more than $90 \%$ of the total input, whereas dissolved riverine and dust inputs could only be significant in the upper $500 \mathrm{~m}$. However, so far only little is known about the importance of the BE in semienclosed and/or interiors basins like the Mediterranean Sea, where atmospheric and river fluxes could also have significant impacts on the $\varepsilon_{\mathrm{Nd}}$ distribution.

As a first approach, we chose to simulate only the Nd isotopic composition $\left(\varepsilon_{\mathrm{Nd}}\right)$ in order to test the BE hypothesis in the Mediterranean Sea (Arsouze et al., 2007). This approach does not require explicitly simulating the $\mathrm{Nd}$ concentration, allowing us to focus on the timescale of the process studied. As in Arsouze et al. $(2007,2010), \varepsilon_{\mathrm{Nd}}$ is implemented in the model as a passive conservative tracer which does not affect ocean circulation. It is transported into the Mediterranean Sea by NEMO-MED12 physical fields using a classical advection-diffusion equation, including the sources and sinks (SMS term, eq1). The rate of change of oceanic $\mathrm{Nd}$ isotopic composition is as follows:

$\frac{\delta \varepsilon_{\mathrm{Nd}}}{\delta t}=S\left(\varepsilon_{\mathrm{Nd}}\right)-U \cdot \nabla \varepsilon_{\mathrm{Nd}}+\nabla \cdot\left(K \nabla \varepsilon_{\mathrm{Nd}}\right)$,

where $S\left(\varepsilon_{\mathrm{Nd}}\right)$ represents the SMS term, $U \cdot \nabla \varepsilon_{\mathrm{Nd}}$ is the three-dimensional advection and $\nabla \cdot\left(K \nabla \varepsilon_{\mathrm{Nd}}\right)$ is the lateral and vertical diffusion of $\varepsilon_{\mathrm{Nd}}$.

Since $\varepsilon_{\mathrm{Nd}}$ is a passive tracer, simulations could be run in offline mode using the pre-computed transport fields $(U$, $V, W$ ) from the NEMO-MED12 dynamical model (Beuvier et al., 2012b). Physical forcing fields are read daily and interpolated at each time step of $20 \mathrm{~min}$. Offline simulations are performed for computational efficiency, allowing many sensitivity tests on the SMS term parameterization. The same approach was used by Ayache et al. (2015b) to simulate the mantle and crustal helium isotope signature, by Ayache et al. (2015a) to model the anthropogenic tritium invasion, and by Palmiéri et al. (2015) to simulate CFCs and anthropogenic carbon storage.

The only SMS term taken into account in the present study is BE (Arsouze et al., 2007, 2010). It is parameterized by a relaxing equation between the ocean and the continental margin:

$S\left(\varepsilon_{\mathrm{Nd}}\right)=1 / \tau\left(\varepsilon_{\mathrm{Ndmargin}}-\varepsilon_{\mathrm{Nd}}\right) \cdot$ mask $_{\text {margin }}$,

where $\tau$ is the characteristic relaxing time (i.e. the characteristic time needed to transfer isotopic properties from the continental margin to the ocean), $\varepsilon_{\mathrm{Nd}}$ is the $\mathrm{Nd}$ isotopic composition of seawater, $\varepsilon_{\text {Ndmargin }}$ is the value of the material deposited along the continental margin (see Sect. 2), and

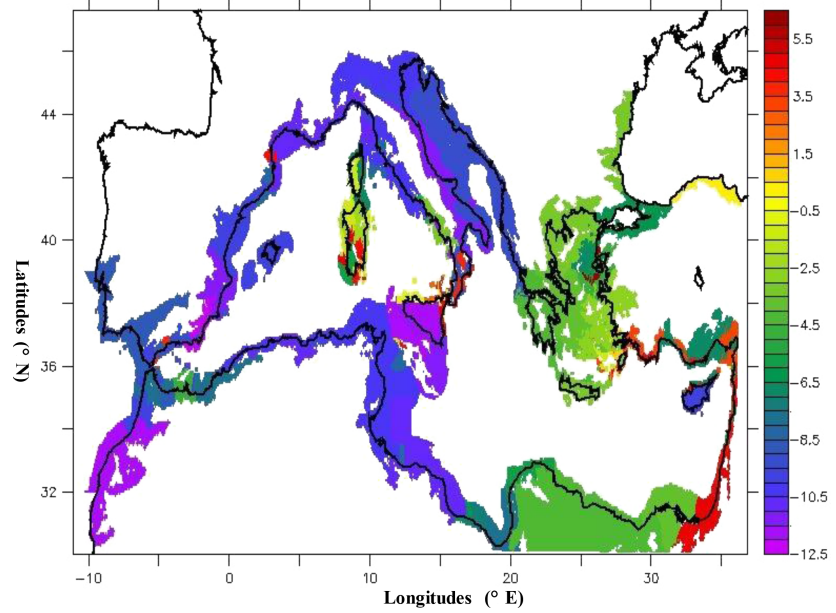

Figure 3. Map of the $\varepsilon \mathrm{Nd}_{\text {margin }}$ used in the model simulation, made by interpolation of Fig. 1b on the oceanic margins of the Mediterranean Sea (see Sect. 2).

mask $k_{\text {margin }}$ is the percentage of continental margin in the grid box which represents the proportion of the surface in the grid where the BE process occurs. This quantity is estimated from the high-resolution bathymetry of the 10th version of the Mercator-LEGOS bathymetry at a resolution of $30^{\prime \prime} \times 30^{\prime \prime}$.

The topographic extension of the oceanic margins of the Mediterranean Sea has been chosen to the $\sim 540 \mathrm{~m}$ (Fig. 3) following the margin definition used to model the iron cycle in the Mediterranean Sea by Palmiéri (2014).

The exchanges of the Nd with the Atlantic Ocean are specified through a buffer zone between $11^{\circ} \mathrm{W}$ and the Strait of Gibraltar. $\varepsilon_{\mathrm{Nd}}$ values in the buffer zone are prescribed from observation using NE Atl. MED-15 vertical profile from Spivack and Wasserburg (1988).

We established some sensitivity experiments regarding the optimal value of $\tau$ in the Mediterranean basin (Arsouze et al., 2007, 2010). In this aim, six tests were performed, referred to as EXP1, EXP2, EXP3 and EXP4 with $\tau=1,3$ months, 6 months and 1 year respectively. As surface ocean currents are generally more dynamic than deep ones, providing more energy for sediment-seawater interactions, we realized an additional simulation (EXP5) wherein $\tau$ increases exponentially with depth from 1 month at the surface to 1 year at $600 \mathrm{~m}$ depth. We also explored the possibility that our BE parameterization might be dependent on the mineralogical maturity of margin sediments (e.g. granitic vs. basaltic). Hence, relaxing time $\tau$ in EXP6 is varying linearly on a timescale of 1 month for the most radiogenic isotopic signature (i.e. $\varepsilon_{\mathrm{Nd}}=+6$ on the extreme east of the Mediterranean margin) to 1 years for the most non-radiogenic values (i.e. $\varepsilon_{\mathrm{Nd}}=-12$ along the Spanish coast).

The simulations were initialized with uniform isotopic composition of $\varepsilon_{\mathrm{Nd}}=-7$ and integrated to steady state; 

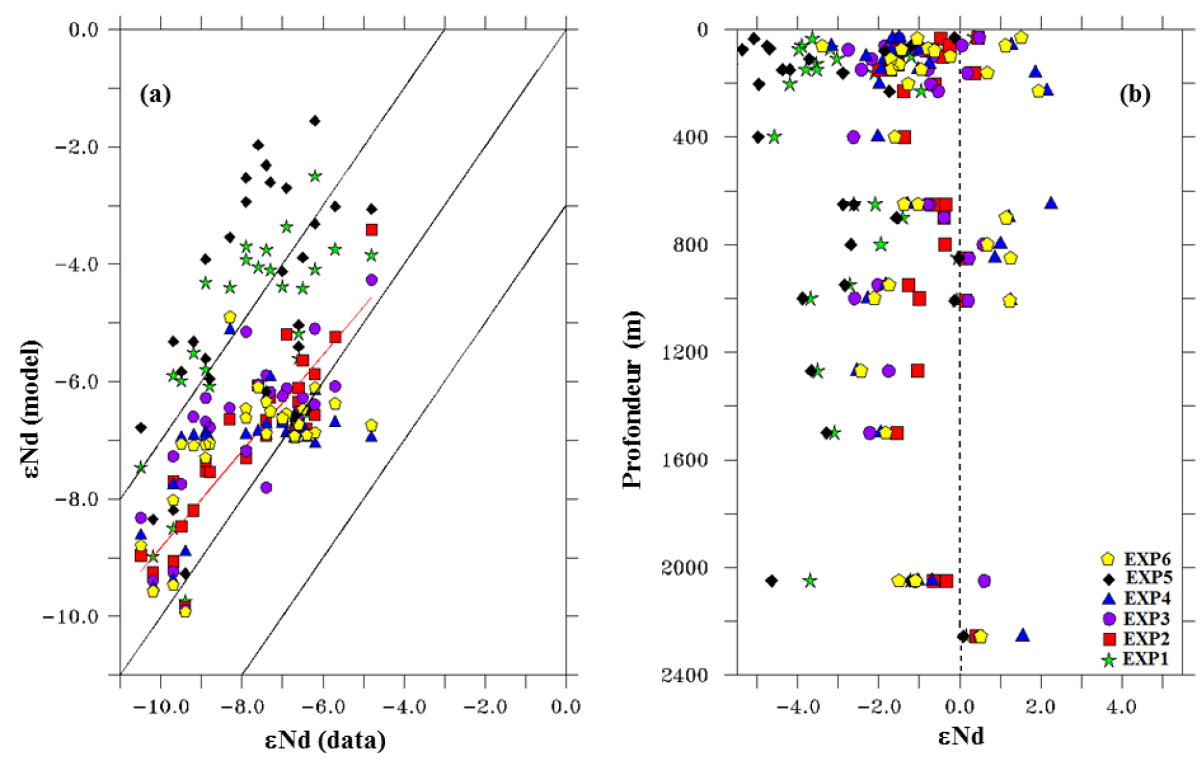

Figure 4. Model-data comparison for the six simulations performed with different relaxing time at the steady state (see Table 3) and the in situ data from Tachikawa et al. (2004), Vance et al. (2004) and Henry et al. (1994): (a) model-data correlation, red line is the linear regression from EXP2. Diagonal dashed lines are lines $\varepsilon \mathrm{Nd}$ (modelled) $=\varepsilon \mathrm{Nd}$ (data), $\varepsilon \mathrm{Nd}$ (modelled) $=\varepsilon \mathrm{Nd}($ data $)+3 \varepsilon \mathrm{Nd}$ and $\varepsilon \mathrm{Nd}($ modelled $)=\varepsilon \mathrm{Nd}$ (data) - 3. (b) Model-data comparison as a function of depth, dashed solid line represents the data from Tachikawa et al. (2004), Vance et al. (2004) and Henry et al. (1994).

i.e. the global averaged drift was less than $10^{-3} \varepsilon_{\mathrm{Nd}}$ per thousand years, for more than 75 years of spin-up run.

\section{Results}

\subsection{Map of the outcropping Nd values}

Results of the Nd parameter mapping are represented in Fig. 2, cold colours represent the old non-radiogenic rocks whereas the warm colours correspond to the recent radiogenic ones.

Tectonic and associated volcanic activities led to the very complex morphology and geology in the Mediterranean region, comprising small islands (e.g. Corsica, Cyprus), subbasins (e.g. Adriatic, Aegean and Tyrrhenian), and many narrow straits (e.g. Strait of Sicily, Otranto Passage). This particular context prevents the use of low-resolution grid to represent this region properly. This motivated the realization of the high-resolution $\left(1 / 12^{\circ} \times 1 / 12^{\circ}\right)$ version of the $\mathrm{Nd}$ isotopic signature (Fig. 2b) and Nd concentration (see Supplement 5) for this basin.

The general trend is that the margin $\mathrm{Nd}$ isotopic signatures vary from non-radiogenic values in the WMed, to radiogenic values when reaching the Aegean and Egyptians coasts, the most radiogenic fields ( $\varepsilon_{\mathrm{Nd}}$ up to +6 ) being located around the eastern border of the Levantine sub-basins, and in the volcanic region of the south of Italy (Fig. 2b). In contrast, the southern Sicilian fields and the northern Alboran sub-basin are characterized by the most negative isotopic sig- nature (values around -12). The Algerian, Tunisian, French and Spanish coasts display relatively homogeneous values between -11.5 and -10 . Such east-west gradient of Nd isotopic signature is also observed in the seawater data, where poorly radiogenic waters from the Atlantic are progressively shifted toward more radiogenic values in the Levantine basin (Tachikawa et al., 2004).

All the details revealed by this new high-resolution map will be used to set boundary conditions in the regional simulation (see Sect. 3, Fig. 3).

\subsection{The characteristic margin-to-ocean exchange time}

We first explored the impact of changing the value of the relaxing time on the $\varepsilon_{\mathrm{Nd}}$ distribution in the Mediterranean Sea. This was made following the strategy adopted by Arsouze et al. (2010) in the North Atlantic basin, although NEMOMED12 model has higher horizontal and vertical resolutions $\left(1 / 12^{\circ}\right.$ in this study compared to $1 / 4^{\circ}$ in Arsouze et al., 2010).

The results of these different sensitivity tests are compared with in situ observations collected by Tachikawa et al. (2004), Vance et al. (2004) and Henry et al. (1994) using correlation plots, coloured maps and sections (Figs. 4 and 5).

The simulated $\varepsilon_{\mathrm{Nd}}$ distributions in EXP2 and EXP3 (relaxing time of 3 and 6 months respectively) present a better correlation with in situ data relative to the other experiments, with correlation coefficients close to 0.75 and 0.60 respectively (Table 3). The difference between in situ data (dashed line) and the different sensitivity experiments as a function of depth (Fig. 4b) reveals that EXP2 provides the best agree- 


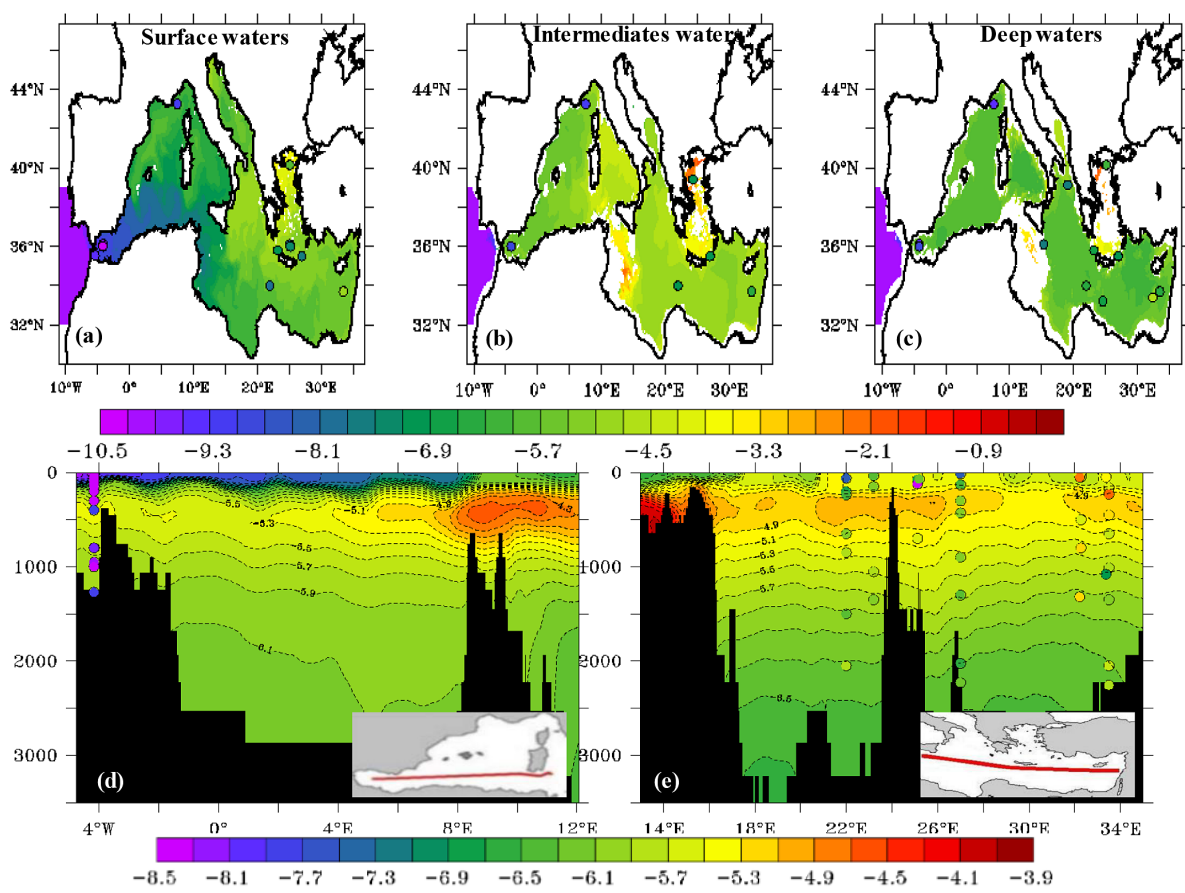

Figure 5. Output of model from EXP2 ( $t=3$ months) at the steady state. Upper panel: horizontal maps for surface waters (a), intermediate waters (b), and deep waters (c). Lower panel E-W section in WMed (d), and EMed (e), whereas colour-filled dots represent in situ observations from Tachikawa et al. (2004), Vance et al. (2004) and Henry et al. (1994). Both use the same colour scale.

ment with observations, despite a slight overestimation of $\varepsilon_{\mathrm{Nd}}$ between 0.3 and $2 \varepsilon_{\mathrm{Nd}}$ units. The data-model differences are more important for the other experiments which produced too-radiogenic simulations (of more than $2 \varepsilon_{\mathrm{Nd}}$ units). The horizontal distribution of $\varepsilon_{\mathrm{Nd}}$ (Supplement 2-4) confirms this statistical correlation, showing that only EXP2 and EXP3 produced reasonable east-west gradients of $\varepsilon_{\mathrm{Nd}}$. EXP1 generated too-pronounced $\varepsilon_{\mathrm{Nd}}$ geographical gradients, particularly in surface waters along the continental margins, suggesting an overestimation of the exchange compared to the transport. On the opposite a simulation with a relaxing time of 1 year (EXP4) leads to a homogeneous $\varepsilon_{\mathrm{Nd}}$ distribution in surface and deep waters with a low data-model correlation, indicating an underestimation of the boundary exchange process. EXP5 ( $\tau$ increases with depth) conducted to a strong gradient over the entire water column in WMed, showing that surface-to-deep variation of the BE rate was likely overestimated in this simulation. EXP6 displayed a realistic E-W gradient in the surface waters, but a too-homogeneous $\varepsilon_{\mathrm{Nd}}$ signal in the intermediate and deep waters, suggesting that the BE rate seems weakly affected by the lithology of the margin sediments. Finally, we consider that the characteristic exchange time providing the best agreement with observations is close to 3 months. This value is consistent with the results obtained by Arsouze et al. (2010) with its simulation of the North Atlantic area. Therefore we will only consider EXP2 for the rest of our analysis.

\subsection{The $\varepsilon_{\mathrm{Nd}}$ distribution}

The monthly-averaged $\varepsilon_{\mathrm{Nd}}$ horizontal distributions resulting from EXP2 for the surface waters $(0-200 \mathrm{~m})$, the intermediate waters $(200-600 \mathrm{~m})$ and the deep waters $(600-3500 \mathrm{~m})$, are represented in Fig. 5a-c respectively, together with the data from Tachikawa et al. (2004), Vance et al. (2004) and Henry et al. (1994). The model results are extracted after the steady state (in 1987) of the simulation and considered representative of a pre-EMT situation (i.e. EMT, Roether et al., 2007).

The model correctly simulates the pronounced $\varepsilon_{\mathrm{Nd}} \mathrm{E}-\mathrm{W}$ gradient characterizing the surface waters (Fig. 5a). The values simulated in the WMed and eastern Levantine basin are consistent with the observations while the simulated values in the Aegean and central Levantine basin tend to be too radiogenic. At intermediate depths, both modelled and observed E-W gradients are less pronounced than at the surface (Fig. 5b). However averaged simulated values are relatively too radiogenic at the intermediate level $(-5.8 \mathrm{com}-$ pared to $-9.4 \pm 0.69$, Table 2). Especially high $\varepsilon_{\mathrm{Nd}}$ signatures are simulated in the Aegean sub-basin, over the Strait of Sicily and in the Tyrrhenian sub-basins (Fig. 5b). A significant model-data disagreement was found in the Alboran sub-basin which largely overestimates the observations. The $\varepsilon_{\mathrm{Nd}}$ distribution in the deep waters is relatively homogeneous over the whole basin except in the Aegean sub-basin and Strait of Sicily (Fig. 5c). 
Table 2. Mean $\varepsilon_{\mathrm{Nd}}$ for the Mediterranean Sea, from EXP3 and for the in situ data from Tachikawa et al. (2004).

\begin{tabular}{llllll}
\hline & \multicolumn{2}{c}{ Model } & & \multicolumn{2}{c}{ In situ data } \\
\cline { 2 - 3 } \cline { 5 - 6 } & $\begin{array}{c}\text { Intermediate } \\
\text { waters }\end{array}$ & $\begin{array}{c}\text { Average } \\
\text { all depths }\end{array}$ & & $\begin{array}{l}\text { Intermediate } \\
\text { waters }\end{array}$ & $\begin{array}{c}\text { Average } \\
\text { all depths }\end{array}$ \\
\hline Mediterranean Sea & -5.8 & -6.2 & & $-7.6 \pm 1.37$ & $-7.8 \pm 1.54$ \\
Eastern basin (EMed) & -4.7 & -5.1 & & $-7 \pm 0.85$ & $-7.1 \pm 1.08$ \\
Western basin (WMed) & -5.8 & -6.3 & & $-9.4 \pm 0.69$ & $-9.6 \pm 0.48$ \\
\hline
\end{tabular}
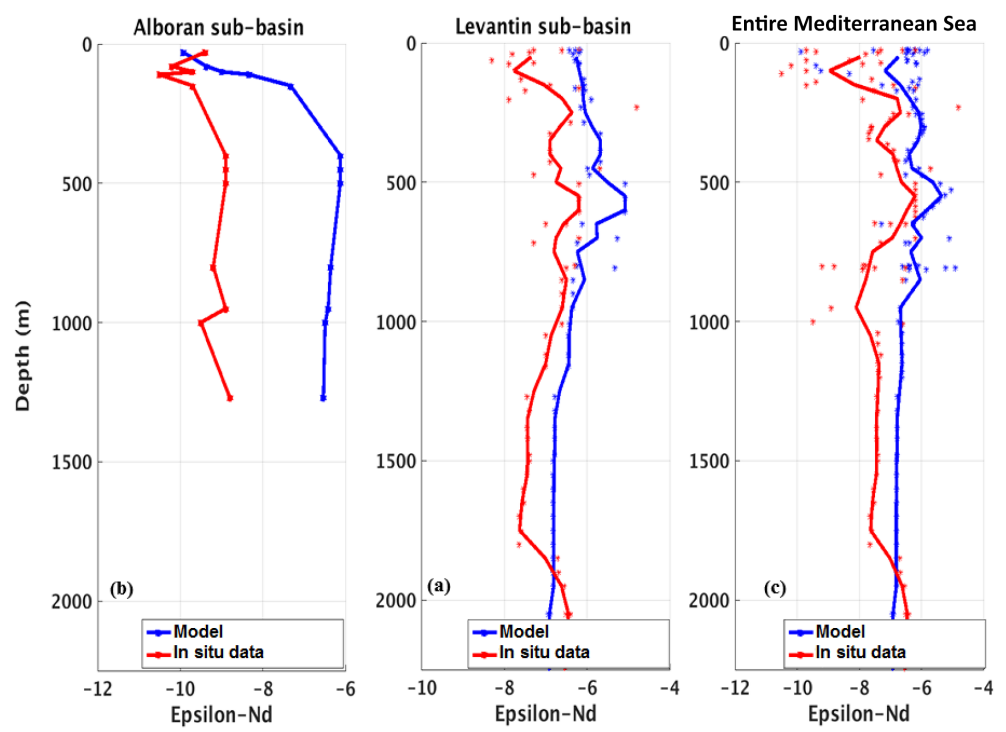

Figure 6. Comparison of average vertical profiles of $\mathrm{Nd}$ isotopic signature (Nd-IC) from EXP2 ( $t=3$ months) in the whole Mediterranean Sea. Model results are in blue, while red indicates the in situ data from Tachikawa et al. (2004), Vance et al. (2004) and Henry et al. (1994).

The Levantine Intermediate Water mass (LIW) is well identified by its marked radiogenic signature. LIW is produced in the Levantine sub-basin before passing Crete at $28^{\circ} \mathrm{E}$, where measured $\varepsilon_{\mathrm{Nd}}$ values reach -5 (Fig. 5). The $\varepsilon_{\mathrm{Nd}}$ isotopic signature is well identified over the entire LIW trajectory at the intermediate level (between 200 and $600 \mathrm{~m}$ depth), with values around -4.8 in the Algerian sub-basin and up to -5.7 in the Alboran sub-basin (Fig. 5d). The resolution of the available data hardly allows us to evaluate the model performance for this water mass; nevertheless, station $74\left(33^{\circ} 7^{\prime} \mathrm{N}, 33^{\circ} 5^{\prime} \mathrm{E}\right)$ in the eastern Levantine basin exhibits a discernible radiogenic signal associated to LIW (more pronounced than the modelled one), while station 51 $\left(33.5^{\circ} \mathrm{N}, 27^{\circ} \mathrm{E}\right)$ in the western Levantine basin exposes a relatively homogeneous vertical isotopic signature. The surface waters originating from the Atlantic Ocean (Atlantic Waters, AW) are characterized by the most negative signature (value around -9) and are transported over all the Mediterranean Sea, allowing them to be clearly identified. The $\varepsilon_{\mathrm{Nd}}$ signatures of the deep-water mass display values around -6.5 , consistent with the observations available in the eastern basin (Fig. 5e).
Except in the Alboran sub-basin, where pronounced mismatches are simulated between the model and the observations, the model captures the general features of the vertical profiles of $\mathrm{Nd}$ isotopic signatures, especially in the Levantine sub-basin (averaged over the entire water column), producing a realistic and significant radiogenic signature associated to LIW at the intermediate level (Fig. 6), although the $\varepsilon_{\mathrm{Nd}}$ values can be overestimated in some places by almost $2 \varepsilon_{\mathrm{Nd}}$ units.

\subsection{The interannual variability}

In this section, we analyse inter annual variations on the redistribution of $\varepsilon_{\mathrm{Nd}}$ over the Mediterranean basin, with a special focus on the possible impact of the EMT events. The evolution of the monthly averaged $\varepsilon_{\mathrm{Nd}}$ at the intermediate level (between 200 and $600 \mathrm{~m}$ ) in different "boxes" following the LIW trajectory from the Levantine sub-basin to the Algerian sub-basin (including Ionian, Strait of Sicily, Tyrrhenian, and Gulf of Lion) is represented in Fig. 7 for the 40 years of the simulation. It shows that $\varepsilon_{\mathrm{Nd}}$ signatures vary seasonally with maximum amplitude of $0.2 \varepsilon_{\mathrm{Nd}}$ units. The EMT event significantly impacts the $\varepsilon_{\mathrm{Nd}}$ signature at the global scale of the 
Table 3. Summary of the main characteristics for each experience.

\begin{tabular}{llc}
\hline Experience & Relaxing time $\tau$ & $\begin{array}{c}\text { Regression } \\
\text { coefficient } \\
\text { for data/model } \\
\text { points }\end{array}$ \\
\hline EXP1 & 1 month & 0.32 \\
EXP2 & 3 months & 0.75 \\
EXP3 & 6 months & 0.60 \\
EXP4 & 1 year & 0.34 \\
EXP5 & $\tau$ varying vertically from 1 month at the $\operatorname{surface}$ to 10 months at $540 \mathrm{~m}$ & 0.27 \\
EXP6 & $\tau 1$ month (max $\left.\varepsilon \mathrm{Nd}_{\text {margin }}\right)$ to 1 year $\left(\min \varepsilon \mathrm{Nd}_{\text {margin }}\right)$ & 0.39 \\
\hline
\end{tabular}
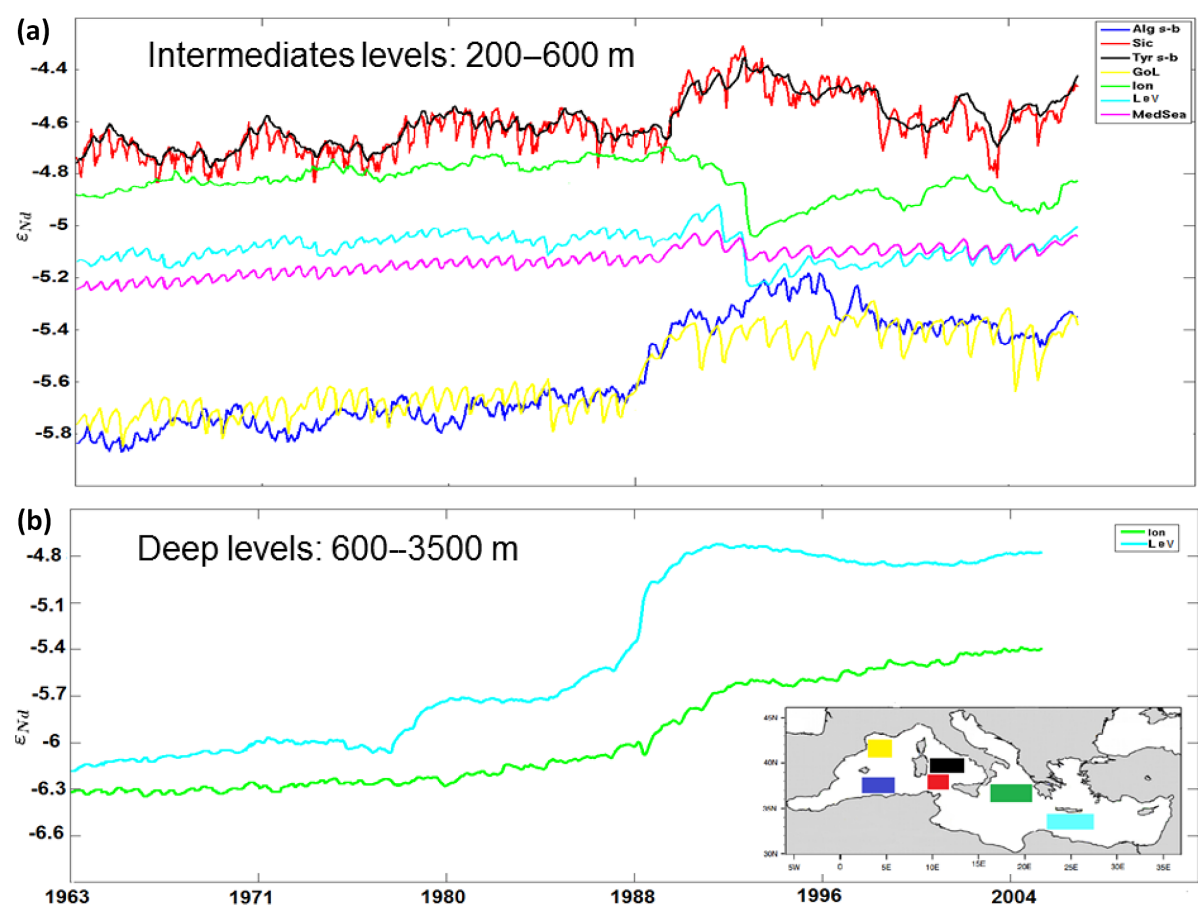

Figure 7. The $\varepsilon \mathrm{Nd}$ evolution from EXP2 ( $\tau=3$ months) at the intermediate level in (a) (average depth between 200 and $600 \mathrm{~m}$ ), and for the deep levels in (b) (average depth between 600 and $3500 \mathrm{~m}$ ). In the Gulf of Lion (yellow), Algerian sub-basin (blue), Levantine s-b (cyan), Ionian s-b (green), Strait of Sicily (red), Tyrrhenian s-b (black).

Mediterranean Sea. After 1992, which is referred to as the beginning of the EMT event, an important change of $\varepsilon_{\mathrm{Nd}}$ distributions is simulated over all the Mediterranean Sea, with regional values shifted by almost $0.5 \varepsilon_{\mathrm{Nd}}$ units.

The drastic change caused by the EMT event at the beginning of the 1990s is further illustrated by showing the differences of $\varepsilon_{\mathrm{Nd}}$ distributions between the pre-EMT situations in 1987 and the subsequent years up to 2010. The analysis on different horizontal levels (Fig. 8), as well as along the EW sections (Fig. 9), provides a better understanding of the source of ventilation for the interior of the Mediterranean Sea, and the connection between the surface, intermediate and deep-water redistribution.
In comparison with the steady-state situation for the Mediterranean Sea circulation (pre-EMT), the surface waters are relatively less radiogenic in the Levantine sub-basin, the Algerian, and the Alboran sub-basins between 1995 and 1999 (Fig. 8a and b). After 2001 these surface waters became more radiogenic over the whole basin. At the intermediate level only the EMed presents a less radiogenic signature in 1995; indeed the $\varepsilon_{\mathrm{Nd}}$ are more radiogenic over the entire basin after 2001 (Fig. 8f-h). The deep waters are globally more radiogenic between 1987 and 2010, especially in the EMed where increase of 1 units of $\varepsilon_{\mathrm{Nd}}$ are simulated around the Aegean sub-basin. The vertical section illustrates the important penetration of the surface and intermediate waters characterized with radiogenic $\varepsilon_{\mathrm{Nd}}$ into the deep waters near 


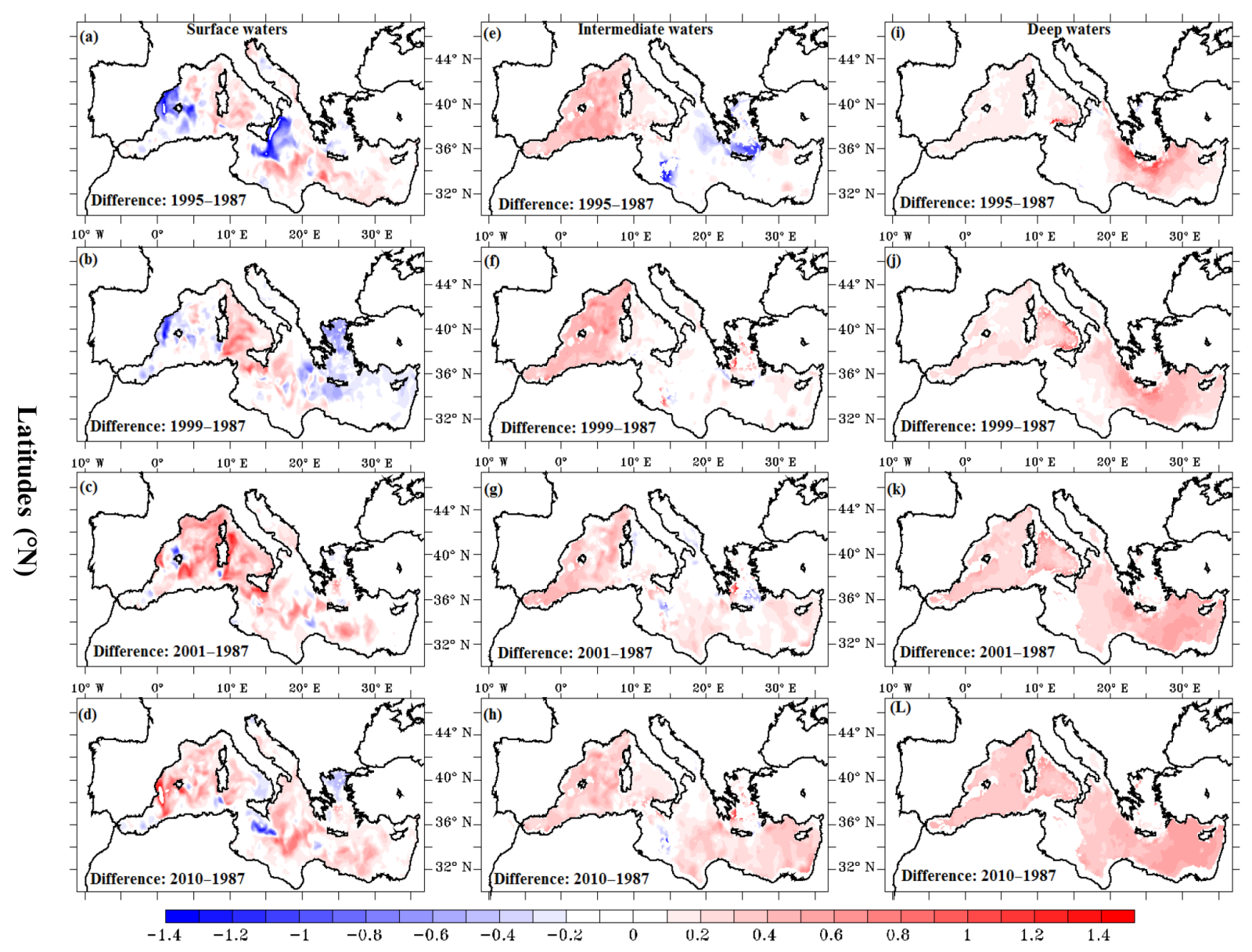

Figure 8. Horizontal maps showing the difference relative to 1987 from EXP2 ( $\tau=3$ month), in the left column for the surface level ( 0 $200 \mathrm{~m}$ ), in the middle column for the intermediate layer (between $250-600 \mathrm{~m}$, and for the deep layer in the right column (600-3500 $\mathrm{m}$ ).

the Cretan Arc as a consequence of the EMT that shifted the $\mathrm{Nd}$ isotopic signature by almost $+1.3 \varepsilon_{\mathrm{Nd}}$ units in the bottom waters (Fig. 7b). This radiogenic signal is maximum in 1995 at the bottom water around the Cretan Arc near $26^{\circ} \mathrm{E}$, and for the following years (i.e. 1997, 1999, 2005 and 2010) propagates in the deep waters of the whole Levantine sub-basin, which typically becomes more radiogenic of +0.5 of $\varepsilon_{\mathrm{Nd}}$ (Fig. 9).

The amplifying tracer penetration caused by the EMT event generates less radiogenic values at the LIW layer in the EMed in 1995 and 1999, because this water is mixed with upwelled pre-EMT less radiogenic water masses. In contrast the simulated values become globally more radiogenic in the WMed. The radiogenic transient signal enters inside the western basin through the LIW outflow (up to $+0.6 \varepsilon_{\mathrm{Nd}}$ unit) and gradually penetrates into the deep water through time. However the most $\varepsilon_{\mathrm{Nd}}$ shift was simulates in the Levantine sub-basin deep water with more than 1.3 unit change (Figs. 7b and 9).

\section{Discussion}

The high-resolution simulation presented here provides a too-radiogenic signature of $\mathrm{Nd}$ isotopic signature in the Mediterranean Sea; nevertheless this approach confirms the primordial role of the $\mathrm{BE}$ as the major source of $\mathrm{Nd}$ in the marine environment, similar to what has been previously demonstrated for the global ocean (Arsouze et al., 2007) and the Atlantic basin (Arsouze et al., 2010). This reinforces the preceding conclusions of $\mathrm{BE}$ as a major process in the $\mathrm{Nd}$ oceanic cycle, even at regional scale and in a semi-enclosed basin such as the Mediterranean basin. Although the processes leading to BE are still not fully understood (Jeandel and Oelkers, 2015), the resulting timescale is of the order of few months, in agreement with Arsouze et al. (2010). This timescale is also consistent with the kinetic rates of Nd release from basaltic material during the batch experiments conducted by Pearce et al. (2013). It is also consistent with the field data and their Lagrangian modelling developed by Grenier et al. (2013) in the highly dynamic south-western Pacific. Taking into account the lithology of the margin sed- 

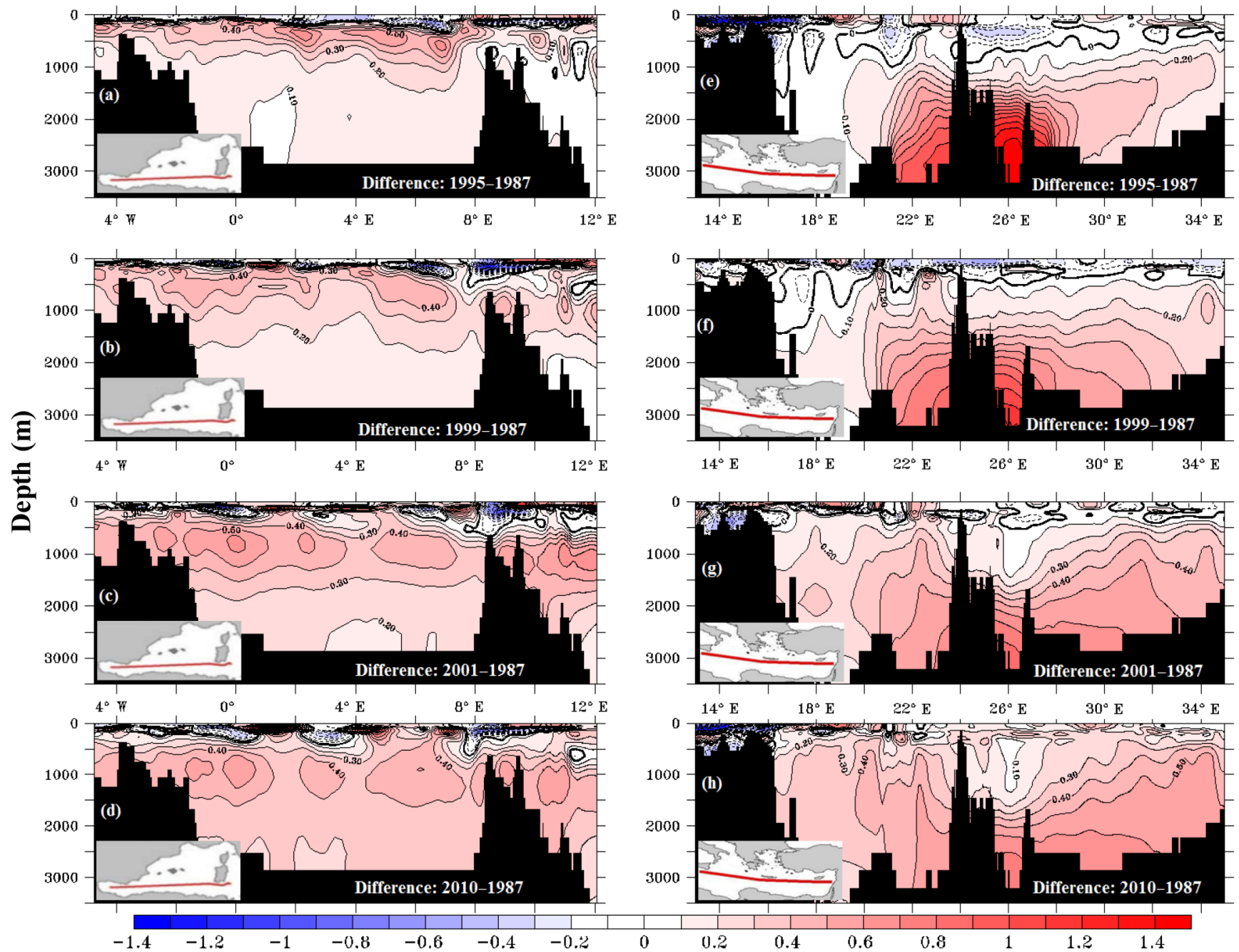

Figure 9. Colour-filled contours represent simulated $\mathrm{Nd}$ isotopic composition for the WMed in the left column, and the EMed sections are shown in the right column. The first line show the situation in 1987 (pre-EMT), the others sections show the difference in the Nd-IC between 1995 and 2010 (post-EMT period) corrected to the 1987 situation.

iments did not improve our simulations. This requires more laboratory experiments, targeted on the issue of the nature of the sediments. Nevertheless the comparison with the available data in the Mediterranean Sea reveals that this approach simulates a slightly too-radiogenic value in the surface and intermediate waters, especially in the Aegean and the Alboran sub-basins. The uniquely available observation in the Alboran sub-basin is located close to the Strait of Gibraltar, and shows $\varepsilon_{\mathrm{Nd}}$ values characteristic of the outflow from the Atlantic sector. The model fails to reproduce this signal associated to the advection of water mass of Atlantic origin (see Fig. 5a), due to a simulated net water flux input from the Atlantic that stands in the lower range compared to observations (Beuvier et al., 2012a). However, the global radiogenic bias will likely be corrected once the dust and river inputs are simulated. Indeed, those could locally affect the surface waters with less radiogenic values. The main river systems of the
Mediterranean basin (i.e. the Nile, Po and Rhone) are characterized by a wide range of $\mathrm{Nd}$ isotopic signature, with an average $\varepsilon_{\mathrm{Nd}}$ value of -10.2 for the Rhone, and rather radiogenic $\mathrm{Nd}$ isotopic ratios for the Nile $\left(\varepsilon_{\mathrm{Nd}} \sim-4\right)$. The input of Saharan dust has important effects on the Mediterranean region (Guerzoni et al., 1997), where the Nd isotopic compositions of aerosols range from -9.2 in the eastern part of northern Africa (e.g. Egypt) to -16 in the central and western parts of northern Africa (Grousset and Biscaye, 2005; Scheuvens et al., 2013). Previous studies suggest that the $\varepsilon_{\mathrm{Nd}}$ distribution at the near surface, for the most part, reflects river and aerosol inputs (Piepgras and Wasserburg, 1987; Arsouze et al., 2009; Jones et al., 2008; Siddall et al., 2008). Hence, it is clear that taking into account dust and river input in future work could improve the simulation of $\mathrm{Nd}$ isotopic distribution in the Mediterranean Sea. 
The LIW layer is particularly characterized by the most radiogenic signature in the intermediate level between 200 and $600 \mathrm{~m}$, which is in good agreement with in situ observations from Tachikawa et al. (2004) especially with the highest $\varepsilon_{\mathrm{Nd}}$ value of -4.8 found at about $200 \mathrm{~m}$ in the easternmost Levantine basin. The LIW represents the principal movement of water mass from the EMed into the WMed. This LIW signature is conserved in the WMed, allowing us to study the impact of interannual variability, including the exceptional events observed in the ventilation of the deep waters (e.g. EMT) in the whole basin. The too-radiogenic isotopic signature simulated in the LIW layer at $25^{\circ} \mathrm{E}$ can be explained by the fact that the LIW are formed NW of Levantine sub-basin near the Cretan Arc, where the margin IC are about -4 , leading to a relatively radiogenic signature as we consider only the margin $\mathrm{Nd}$ source. Also, tritium/helium (Ayache et al., 2015a) and CFC (Palmiéri et al., 2015) simulations have shown that the model overestimates the mixing near the Cretan Arc and, as a consequence, the Levantine sub-basin isotopic signature is overrepresented in this water mass.

The sequence of the EMT events occurring in the EMed at the beginning of the 1990s has completely changed the deep-water mass structure. Different hypotheses concerning the preconditioning of the EMT and its timing have been proposed in the literature (Roether et al., 1996, 2007; MalanotteRizzoli et al., 1999; Lascaratos et al., 1999; Theocharis et al., 1992, 1999; Theocharis and Kontoyiannis, 1999; Samuel et al., 1999; Zervakis et al., 2000; Stanev and Peneva, 2002; Klein et al., 1999; Gertman et al., 2006; Josey, 2003). In our simulation, the $\varepsilon_{\mathrm{Nd}}$ distribution between 1995 and 2001 also revealed that LIW and deep-water signatures were very different from the pre-EMT picture (see Fig. 7). This amplification of mixing caused by the EMT generates accumulation of radiogenic water at the bottom. The 1995 section emphasizes the severe impact of the EMT on water mass distribution, which transfers massive volumes of surface/intermediate waters into the deep layers, with the highest contributions toward the bottom and south of Crete (Fig. 8), causing a temporary change in the EMDW origin, from the Adriatic to Aegean sub-basin in 1992-1993. The renewal of the deepwater masses is very similar to the tritium/helium- 3 redistribution observed by Roether et al. (2013), which is satisfyingly simulated by our regional model (Ayache et al., 2015a). This gives some more reliability to the evolution of $\varepsilon_{\mathrm{Nd}}$ distribution simulated after the EMT event (Fig. 9).

The EMT modifies the characteristics of EMDW in the Levantine sub-basin by increasing the $\varepsilon_{\mathrm{Nd}}$ signature over the entire eastern basin (Fig. 9). Hence the LIW layer is also affected by this $\varepsilon_{\mathrm{Nd}}$ shift, which is next transferred rapidly in the WMed by the overflow of the Strait of Sicily. The LIW signal then propagates at depth in the western basin, illustrating how the EMT event modifies water mass characteristics and potentially affects the formation of deep and bottom water masses in this sub-basin.
Our results suggest that the shift is more important in the Levantine deep water, compared to intermediate water where the EMT impact is lower. This sensitivity test gives a useful diagnostic on the long-term variability of Mediterranean Sea circulation and demonstrates the potential of $\mathrm{Nd}$ to detect a EMT-like event. However the weak formation of AdDW could affect the simulated sift of seawater Nd IC in the Ionian deep water.

\section{Conclusions}

This study proposes a new map compiled from in situ data with a sufficient resolution to cover the very complex morphology and geology of the Mediterranean Sea. This map shows Nd isotopic signatures for all the Mediterranean Sea margins. The quality of this interpolated map means it can be used as a continuous source of $\varepsilon_{\mathrm{Nd}}$ to make a link between an ocean circulation model and the tracer inputs from the margins in order to better understand the thermohaline circulation in modern and palaeo ocean circulation. This compilation provides a complete picture of the $\varepsilon_{\mathrm{Nd}}$ of the whole Mediterranean margins which could interest other earth science fields (e.g. solid earth, weathering, tectonic, etc.).

The $\varepsilon_{\mathrm{Nd}}$ distribution was simulated using a high-resolution regional model at $1 / 12^{\circ}$ of horizontal resolution $(6-8 \mathrm{~km})$. The boundary exchange (BE) parameterization was performed via a relaxing term toward the isotopic composition of the margin from this new geological map. The characteristic margin-to-ocean exchange time is about 3 months in the Mediterranean Sea, in good agreement with the previous estimation of Arsouze et al. (2010) in the northern Atlantic basin. The high resolution of the geological field on the one hand and the model on the other hand has revealed local heterogeneities attributed to local BE effects that would not be detected using a coarse-resolution model. This is not confirmed by the data yet but they could be improved when all the measurements done in the framework of MedBlack Geotraces cruise are available.

Our next step is therefore to use a fully prognostic coupled dynamical/biogeochemical model with an explicit representation of all $\mathrm{Nd}$ sources (i.e. atmospheric dusts, dissolved river fluxes, and margin sediment re-dissolution) and sinks (i.e. scavenging) to simulate the $\mathrm{Nd}$ oceanic cycle in another dedicated study. More in situ data should help to improve knowledge of $\mathrm{Nd}$ and its isotope cycles in the Mediterranean Sea, which will better constrain the fluxes of solid material and exchange between the continental margin and open ocean.

The boundary sources with $\varepsilon_{\mathrm{Nd}}$ implemented as a passive conservative has represented an interesting opportunity to explore the interannual variability on the $\varepsilon_{\mathrm{Nd}}$ distribution. Indeed, the Eastern Mediterranean Transient (EMT) signal from the Aegean sub-basin was simulated, conducting a significant and measurable evolution of $\varepsilon_{\mathrm{Nd}}$ signal over the 
whole Mediterranean basin. It confirms that $\varepsilon_{\mathrm{Nd}}$ represents an appropriate proxy to improve our knowledge on the longterm trend in the Mediterranean Sea circulation, especially to explore whether EMT-type events occurred in the past (Roether et al., 2014; Gačić et al., 2011). New Nd palaeo data (e.g. Jiménez-Espejo et al., 2015) or recent Nd observations collected on corals or foraminifera in the context of the PaleoMeX (Palaeo Mediterranean Experiment) programme should give an opportunity to address this question.

\section{Data availability}

The data used in this study was obtained from an extensive compilation of all published $\mathrm{Nd}$ concentrations and isotopic values using the EarthChem database (accessible from http:// www.earthchem.org). All supplemental figures and data references (Sect. 2) can be found in the Supplement.

\section{The Supplement related to this article is available online at doi:10.5194/bg-13-5259-2016-supplement.}

Acknowledgements. We would like to thank Koji Suzuki and an anonymous reviewer for their careful reading of the manuscript and helpful remarks. The authors wish to acknowledge F. Bassinot, G. Tranchida and P. Censi for sediment samples. We thank S. Conticelli who kindly answered our questions on geological features of the Italian coast, which greatly helped for the interpolation. Hugo Pradalier is acknowledged for his contribution at the beginning of this work.

Edited by: K. Suzuki

Reviewed by: two anonymous referees

\section{References}

Allegre, C.: Géologie Isotopique, Belin, Paris, 2005.

Antonov, J. I., Locarnini, R. A., Boyer, T. P., Mishonov, A. V., and Garcia, H. E.: World Ocean Atlas 2005, in: Volume 2: Salinity, edited by: Levitus, S., NOAA Atlas NESDIS 62, US Government Printing Office, Washington, D.C., 182 pp., 2006.

Arsouze, T., Dutay, J. C., Lacan, F., and Jeandel, C.: Modeling the neodymium isotopic composition with a global ocean circulation model, Chem. Geol., 239, 165-177, doi:10.1016/j.chemgeo.2006.12.006, 2007.

Arsouze, T., Dutay, J.-C., Kageyama, M., Lacan, F., Alkama, R., Marti, O., and Jeandel, C.: A modeling sensitivity study of the influence of the Atlantic meridional overturning circulation on neodymium isotopic composition at the Last Glacial Maximum, Clim. Past, 4, 191-203, doi:10.5194/cp-4-191-2008, 2008.

Arsouze, T., Dutay, J.-C., Lacan, F., and Jeandel, C.: Reconstructing the Nd oceanic cycle using a coupled dynamical - biogeochemical model, Biogeosciences, 6, 2829-2846, doi:10.5194/bg6-2829-2009, 2009.
Arsouze, T., Treguier, A. M., Peronne, S., Dutay, J. C., Lacan, F., and Jeandel, C.: Modeling the Nd isotopic composition in the North Atlantic basin using an eddy-permitting model, Ocean Science, 6, 789-797, doi:10.5194/os-6-789-2010, 2010.

Ayache, M., Dutay, J.-C., Jean-Baptiste, P., Beranger, K., Arsouze, T., Beuvier, J., Palmieri, J., Le-vu, B., and Roether, W.: Modelling of the anthropogenic tritium transient and its decay product helium-3 in the Mediterranean Sea using a high-resolution regional model, Ocean Science, 11, 323-342, doi:10.5194/os-11323-2015, 2015a.

Ayache, M., Dutay, J.-C., Jean-Baptiste, P., and Fourré, E.: Simulation of the mantle and crustal helium isotope signature in the Mediterranean Sea using a high-resolution regional circulation model, Ocean Science, 11, 965-978, doi:10.5194/os-11965-2015, 2015b.

Bertram, C. and Elderfield, H.: The geochemical balance of the rare earth elements and neodymium isotopes in the oceans, Geochim. Cosmochim. Ac., 57, 1957-1986, doi:10.1016/00167037(93)90087-D, 1993.

Beuvier, J., Sevault, F., Herrmann, M., Kontoyiannis, H., Ludwig, W., Rixen, M., Stanev, E., Béranger, K., and Somot, S.: Modeling the Mediterranean Sea interannual variability during 1961-2000: Focus on the Eastern Mediterranean Transient, J. Geophys. Res., 115, C08017, doi:10.1029/2009JC005950, 2010.

Beuvier, J., Béranger, K., Lebeaupin Brossier, C., Somot, S., Sevault, F., Drillet, Y., Bourdallé-Badie, R., Ferry, N., and Lyard, F. Spreading of the Western Mediterranean Deep Water after winter 2005: Time scales and deep cyclone transport, J. Geophys. Res., 117, C07022, doi:10.1029/2011JC007679, 2012a.

Beuvier, J., Lebeaupin Brossier, C., Béranger, K., Arsouze, T., Bourdallé-Badie, R., Deltel, C., Drillet, Y., Drobinski, P., Lyard, F., Ferry, N., Sevault, F., and Somot, S.: MED12, Oceanic component for the modelling of the regional Mediterranean Earth System, Mercator Ocean Quarterly Newsletter, 46, 60-66, 2012b.

Carter, P., Vance, D., Hillenbrand, C., Smith, J., and Shoosmith, D.: The neodymium isotopic composition of waters masses in the eastern Pacific sector of the Southern Ocean, Geochim. Cosmochim. Ac., 79, 41-59, doi:10.1016/j.gca.2011.11.034, 2012.

Conticelli, S., Guarnieri, L., Farinelli, A., Mattei, M., Avanzinelli, R., Bianchini, G., Boari, E., Tommasini, S., Tiepolo, M., Prelević, D., and Venturelli, G.: Trace elements and $\mathrm{Sr}-\mathrm{Nd}-\mathrm{Pb}$ isotopes of K-rich, shoshonitic, and calc-alkaline magmatism of the Western Mediterranean Region: Genesis of ultrapotassic to calcalkaline magmatic associations in a post-collisional geodynamic setting, Lithos, 107, 68-92, doi:10.1016/j.lithos.2008.07.016, 2009.

Drobinski, P., Anav, A., Lebeaupin Brossier, C., Samson, G., Stéfanon, M., Bastin, S., Baklouti, M., Béranger, K., Beuvier, J., Bourdallé-Badie, R., Coquart, L., D’Andrea, F., de NobletDucoudré, N., Diaz, F., Dutay, J.-C., Ethe, C., Foujols, M.A., Khvorostyanov, D., Madec, G., Mancip, M., Masson, S., Menut, L., Palmieri, J., Polcher, J., Turquety, S., Valcke, S., and Viovy, N.: Model of the Regional Coupled Earth system (MORCE): Application to process and climate studies in vulnerable regions, Environ. Model. Softw., 35, 1-18, doi:10.1016/j.envsoft.2012.01.017, 2012.

Elderfield, H., Upstill-Goddard, R., and Sholkovitz, E.: The rare earth elements in rivers, estuaries, and coastal seas and their sig- 
nificance to the composition of ocean waters, Geochim. Cosmochim. Ac., 54, 971-991, doi:10.1016/0016-7037(90)90432K, 1990.

Frank, M.: Radiogenic isotopes: Tracers of past ocean circulation and erosional input, Rev. Geophys., 40, 1001, doi:10.1029/2000RG000094, 2002.

Frost, C., O'Nions, R., and Goldstein, S.: Mass balance for Nd in the Mediterranean Sea, Chem. Geol., 55, 45-50, 1986.

Gačić, M., Civitarese, G., Eusebi Borzelli, G. L., Kovačević, V., Poulain, P.-M., Theocharis, A., Menna, M., Catucci, A., and Zarokanellos, N.: On the relationship between the decadal oscillations of the northern Ionian Sea and the salinity distributions in the eastern Mediterranean, J. Geophys. Res., 116, C12002, doi:10.1029/2011JC007280, 2011.

Garcia-Solsona, E., Jeandel, C., Labatut, M., Lacan, F., Vance, D., Chavagnac, V., and Pradoux, C.: Rare earth elements and Nd isotopes tracing water mass mixing and particle-seawater interactions in the SE Atlantic, Geochim. Cosmochim. Ac., 125, 351372, doi:10.1016/j.gca.2013.10.009, 2014.

Gertman, I., Pinardi, N., Popov, Y., and Hecht, A.: Aegean Sea Water Masses during the Early Stages of the Eastern Mediterranean Climatic Transient (1988-90), J. Phys. Oceanogr., 36, 1841-1859, doi:10.1175/JPO2940.1, 2006.

Goldstein, S. L. and Hemming, S. R.: Long-lived Isotopic Tracers in Oceanography, Paleoceanography, and Ice-sheet Dynamics, Treat. Geochem., 8, 453-483, doi:10.1016/B978-0-08-0959757.00617-3, 2003.

Goldstein, S. L., O’Nions, R., and Hamilton, P.: A Sm-Nd isotopic study of atmospheric dusts and particulates from major river systems, Earth Planet. Sc. Lett., 70, 221-236, doi:10.1016/0012821X(84)90007-4, 1984.

Goldstein, S. L., Arndt, N., and Stallard, R.: The history of a continent from $\mathrm{U}-\mathrm{Pb}$ ages of zircons from Orinoco River sand and $\mathrm{Sm}-\mathrm{Nd}$ isotopes in Orinoco basin river sediments, Chem. Geol., 139, 271-286, doi:10.1016/S0009-2541(97)00039-9, 1997.

Greaves, M. J., Rudnicki, M., and Elderfield, H.: Rare earth elements in the Mediterranean Sea and mixing in the Mediterranean outflow, Earth Planet. Sc. Lett., 103, 169-181, doi:10.1016/0012821X(91)90158-E, 1991.

Grenier, M., Jeandel, C., Lacan, F., Vance, D., Venchiarutti, C., Cros, A., and Cravatte, S.: From the subtropics to the central equatorial Pacific Ocean: neodymium isotopic composition and rare earth element concentration variations, J. Geophys. Res.Oceans, 118, 592-618, 2013.

Grousset, F. E. and Biscaye, P. E.: Tracing dust sources and transport patterns using $\mathrm{Sr}, \mathrm{Nd}$ and $\mathrm{Pb}$ isotopes, Chem. Geol., 222, 149-167, doi:10.1016/j.chemgeo.2005.05.006, 2005.

Guerzoni, S., Molinaroli, E., and Chester, R.: Saharan dust input to the western Mediterranean Sea: depositional patterns, geochemistry and sedimentology implications, Deep-Sea Res. Pt. II, 44, 631-654, 1997.

Guyennon, A., Baklouti, M., Diaz, F., Palmieri, J., Beuvier, J., Lebaupin-Brossier, C., Arsouze, T., Béranger, K., Dutay, J.-C., and Moutin, T.: New insights into the organic carbon export in the Mediterranean Sea from 3-D modeling, Biogeosciences, 12, 7025-7046, doi:10.5194/bg-12-7025-2015, 2015.

Haley, B. A., Frank, M., Hathorne, E., and Pisias, N.: Biogeochemical implications from dissolved rare earth element and $\mathrm{Nd}$ iso- tope distributions in the Gulf of Alaska, Geochim. Cosmochim. Ac., 126, 455-474, doi:10.1016/j.gca.2013.11.012, 2014.

Henry, F., Jeandel, C., Dupré, B., and Minster, J.-F.: Particulate and dissolved $\mathrm{Nd}$ in the western Mediterranean Sea: Sources, fate and budget, Mar. Chem., 45, 283-305, doi:10.1016/03044203(94)90075-2, 1994.

Herrmann, M., Sevault, F., Beuvier, J., and Somot, S.: What induced the exceptional 2005 convection event in the northwestern Mediterranean basin? Answers from a modeling study, J. Geophys. Res., 115, C12051, doi:10.1029/2010JC006162, 2010.

Herrmann, M. J. and Somot, S.: Relevance of ERA40 dynamical downscaling for modeling deep convection in the Mediterranean Sea, Geophys. Res. Lett., 35, L04607, doi:10.1029/2007GL032442, 2008.

Jacobsen, S. B. and Wasserburg, G. J.: Sm-Nd isotopic evolution of chondrites, Earth Planet. Sc. Lett., 50, 139-155, 1980.

Jeandel, C.: Concentration and isotopic composition of $\mathrm{Nd}$ in the South Atlantic Ocean, Earth Planet. Sc. Lett., 117, 581-591, doi:10.1016/0012-821X(93)90104-H, 1993.

Jeandel, C. and Oelkers, E. H.: The influence of terrigenous particulate material dissolution on ocean chemistry and global element cycles, Chem. Geol., 395, 50-66, doi:10.1016/j.chemgeo.2014.12.001, 2015.

Jeandel, C., Bishop, J. K., and Zindler, A.: Exchange of neodymium and its isotopes between seawater and small and large particles in the Sargasso Sea, Geochim. Cosmochim. Ac., 59, 535-547, doi:10.1016/0016-7037(94)00367-U, 1995.

Jeandel, C., Thouron, D., and Fieux, M.: Concentrations and isotopic compositions of neodymium in the eastern Indian Ocean and Indonesian straits, Geochim. Cosmochim. Ac., 62, 25972607, doi:10.1016/S0016-7037(98)00169-0, 1998.

Jeandel, C., Arsouze, T., Lacan, F., Téchiné, P., and Dutay, J. C.: Isotopic $\mathrm{Nd}$ compositions and concentrations of the lithogenic inputs into the ocean: A compilation, with an emphasis on the margins, Chem. Geol., 239, 156-164, doi:10.1016/j.chemgeo.2006.11.013, 2007.

Jiménez-Espejo, F., Pardos-Gené, M., Martínez-Ruiz, F., GarcíaAlix, A., van de Flierdt, T., Toyofuku, T., Bahr, A., and Kreissig, K.: Geochemical evidence for intermediate water circulation in the westernmost Mediterranean over the last $20 \mathrm{kyr} \mathrm{BP}$ and its impact on the Mediterranean Outflow, Global Planet. Change, 135, 38-46, doi:10.1016/j.gloplacha.2015.10.001, 2015.

Jones, K. M., Khatiwala, S. P., Goldstein, S. L., Hemming, S. R., and van de Flierdt, T.: Modeling the distribution of $\mathrm{Nd}$ isotopes in the oceans using an ocean general circulation model, Earth Planet. Sc. Lett., 272, 610-619, doi:10.1016/j.epsl.2008.05.027, 2008.

Josey, S. A.: Changes in the heat and freshwater forcing of the eastern Mediterranean and their influence on deep water formation, J. Geophys. Res., 108, 3237, doi:10.1029/2003JC001778, 2003.

Klein, B., Roether, W., Manca, B., Bregant, D., Beitzel, V., Kovacevic, V., and Luchetta, A.: The large deep water transient in the Eastern Mediterranean, Deep-Sea Res., 46, 371-414, 1999.

Lacan, F. and Jeandel, C.: Acquisition of the neodymium isotopic composition of the North Atlantic Deep Water, Geochem. Geophy. Geosy., 6, Q12008, doi:10.1029/2005GC000956, 2005.

Lacan, F., Tachikawa, K., and Jeandel, C.: Neodymium isotopic composition of the oceans: A compilation 
of seawater data, Chem. Geol., 300-301, 177-184, doi:10.1016/j.chemgeo.2012.01.019, 2012.

Lascaratos, A., Roether, W., Nittis, K., and Klein, B.: Recent changes in deep water formation and spreading in the eastern Mediterranean Sea: a review, Prog. Oceanogr., 44, 5-36, doi:10.1016/S0079-6611(99)00019-1, 1999.

Lelieveld, J., Berresheim, H., Borrmann, S., Crutzen, P. J., Dentener, F. J., Fischer, H., Feichter, J., Flatau, P. J., Heland, J., Holzinger, R., Korrmann, R., Lawrence, M. G., Levin, Z., Markowicz, K. M., Mihalopoulos, N., Minikin, A., Ramanathan, V., De Reus, M., Roelofs, G. J., Scheeren, H. A., Sciare, J., Schlager, H., Schultz, M., Siegmund, P., Steil, B., Stephanou, E. G., Stier, P., Traub, M., Warneke, C., Williams, J., and Ziereis, H.: Global air pollution crossroads over the Mediterranean, Science, 298, 794-799, doi:10.1126/science.1075457, 2002.

Leveau, M. and Coste, B.: Impact des apports rhodaniens sur le milieu pelagique du golfe du Lion, Bull. Ecol., 18, 119-112, 1987.

Locarnini, R. A., Mishonov, A. V., Antonov, J. I., Boyer, T. P., and Garcia, H. E.: World Ocean Atlas 2005, in: Volume 1: Temperature, edited by: Levitus, S., NOAA Atlas NESDIS 61, US Government Printing Office, Washington, D.C., 182 pp., 2006.

Ludwig, W., Dumont, E., Meybeck, M., and Heussner, S.: River discharges of water and nutrients to the Mediterranean and Black Sea: Major drivers for ecosystem changes during past and future decades?, Prog. Oceanogr., 80, 199-217, doi:10.1016/j.pocean.2009.02.001, 2009.

Madec, G. and NEMO-Team.: Note du Pôle de modélisation, NEMO ocean engine, 27, Institut Pierre-Simon Laplace (IPSL), France, 2008.

Malanotte-Rizzoli, P. and Robinson, A. R.: POEM: Physical Oceanography of the Eastern Miditerranean, EOS Trans. Am. Geophys. Un., 69, 194, doi:10.1029/88EO00125, 1988.

Malanotte-Rizzoli, P., Manca, B. B., D’Alcala, M. R., Theocharis, A., Brenner, S., Budillon, G., and Ozsoy, E.: The Eastern Mediterranean in the 80s and in the 90s: the big transition in the intermediate and deep circulations, Dynam. Atmos. Oceans, 29, 365-395, doi:10.1016/S0377-0265(99)00011-1, 1999.

Martin, E., MacLeod, K., Jiménez Berrocoso, A., and Bourbon, E.: Water mass circulation on Demerara Rise during the Late Cretaceous based on Nd isotopes, Earth Planet. Sc. Lett., 327-328, 111-120, doi:10.1016/j.eps1.2012.01.037, 2012.

MEDAR-MedAtlas-group: Medar-Medatlas Protocol (Version 3) Part I: Exchange Format and Quality Checks for Observed Profiles, P. Rap. Int. IFREMER/TMSI/IDM/SIS002-006, Brest, p. 50, 2002.

MerMex-Group: Marine ecosystems' responses to climatic and anthropogenic forcings in the Mediterranean, Prog. Oceanogr., 91, 97-166, doi:10.1016/j.pocean.2011.02.003, 2011.

Mignot, A., Claustre, H., Uitz, J., Poteau, A., Ortenzio, F. D., and Xing, X.: Understanding the seasonal dynamics of phytoplankton biomass and the deep chlorophyll maximum in oligotrophic environments: A Bio-Argo float investigation, Global Biogeochem. Cy., 28, 856-876, doi:10.1002/2013GB004781, 2014.

Millot, C. and Taupier-Letage, I.: Circulation in the Mediterranean Sea, Handb. Environ. Chem., 5, 29-66, 2005.

Molina-Kescher, M., Frank, M., and Hathorne, E. C.: Nd and Sr isotope compositions of different phases of surface sediments in the South Pacific: Extraction of seawater signatures, boundary ex- change, and detrital/dust provenance, Geochem. Geophy. Geosy., 15, 3502-3520, doi:10.1002/2014GC005443, 2014.

Nabat, P., Somot, S., Mallet, M., Sevault, F., Chiacchio, M., and Wild, M.: Direct and semi-direct aerosol radiative effect on the Mediterranean climate variability using a coupled regional climate system model, Clim. Dynam., 44, 1127-1155, doi:10.1007/s00382-014-2205-6, 2014.

O’Nions, R. K., Evensen, N. M., and Hamilton, P. J.: Geochemical modeling of mantle differentiation and crustal growth, J. Geophys. Res., 84, 6091, doi:10.1029/JB084iB11p06091, 1979.

Owen, J. P.: Geochemistry of lamprophyres from the Western Alps, Italy: implications for the origin of an enriched isotopic component in the Italian mantle, Contrib. Mineral. Petrol., 155, 341362, doi:10.1007/s00410-007-0246-0, 2007.

Palmiéri, J.: Modélisation biogéochimique de la mer Méditerranée avec le modèle régional couplé NEMO-MED12/PISCES, Sciences de la Terre, Université de Versailles-Saint Quentin en Yvelines, 2014.

Palmiéri, J., Orr, J. C., Dutay, J.-C., Béranger, K., Schneider, A., Beuvier, J., and Somot, S.: Simulated anthropogenic $\mathrm{CO}_{2}$ storage and acidification of the Mediterranean Sea, Biogeosciences, 12, 781-802, doi:10.5194/bg-12-781-2015, 2015.

Pearce, C. R., Jones, M. T., Oelkers, E. H., Pradoux, C., and Jeandel, C.: The effect of particulate dissolution on the neodymium (Nd) isotope and Rare Earth Element (REE) composition of seawater, Earth Planet. Sc. Lett., 369-370, 138-147, doi:10.1016/j.eps1.2013.03.023, 2013.

Pena, L. D., Goldstein, S. L., Hemming, S. R., Jones, K. M., Calvo, E., Pelejero, C., and Cacho, I.: Rapid changes in meridional advection of Southern Ocean intermediate waters to the tropical Pacific during the last $30 \mathrm{kyr}$, Earth Planet. Sc. Lett., 368, 20-32, doi:10.1016/j.epsl.2013.02.028, 2013.

Piepgras, D. J. and Wasserburg, G. J.: Rare earth element transport in the western North Atlantic inferred from $\mathrm{Nd}$ isotopic observations, Geochim. Cosmochim. Ac., 51, 1257-1271, doi:10.1016/0016-7037(87)90217-1, 1987.

Piotrowski, A. M., Goldstein, S. L., Hemming, S. R., and Fairbanks, R. G.: Intensification and variability of ocean thermohaline circulation through the last deglaciation, Earth Planet. Sc. Lett., 225, 205-220, doi:10.1016/j.eps1.2004.06.002, 2004.

Piotrowski, A. M., Galy, A., Nicholl, J., Roberts, N., Wilson, D., Clegg, J., and Yu, J.: Reconstructing deglacial North and South Atlantic deep water sourcing using foraminiferal Nd isotopes, Earth Planet. Sc. Lett., 357-358, 289-297, doi:10.1016/j.eps1.2012.09.036, 2012.

Prelević, D., Foley, S., Romer, R., and Conticelli, S.: Mediterranean Tertiary lamproites derived from multiple source components in postcollisional geodynamics, Geochim. Cosmochim. Ac., 72, 2125-2156, doi:10.1016/j.gca.2008.01.029, 2008.

Rempfer, J., Stocker, T. F., Joos, F., Dutay, J. C., and Siddall, M.: Modelling Nd-isotopes with a coarse resolution ocean circulation model: Sensitivities to model parameters and source/sink distributions, Geochim. Cosmochim. Ac., 75, 59275950, doi:10.1016/j.gca.2011.07.044, 2011.

Révillon, S., Jouet, G., Bayon, G., Rabineau, M., Dennielou, B., Hémond, C., and Berné, S.: The provenance of sediments in the Gulf of Lions, western Mediterranean Sea, Geochem. Geophy. Geosy., 12, Q08006, doi:10.1029/2011GC003523, 2011. 
Rickli, J., Frank, M., and Halliday, A. N.: The hafnium-neodymium isotopic composition of Atlantic seawater, Earth Planet. Sc. Lett., 280, 118-127, doi:10.1016/j.epsl.2009.01.026, 2009.

Rickli, J., Frank, M., Baker, A., Aciego, S., de Souza, G., Georg, R., and Halliday, A.: Hafnium and neodymium isotopes in surface waters of the eastern Atlantic Ocean: Implications for sources and inputs of trace metals to the ocean, Geochim. Cosmochim. Ac., 74, 540-557, doi:10.1016/j.gca.2009.10.006, 2010.

Rixen, M., Beckers, J. M., Levitus, S., Antonov, J., Boyer, T., Maillard, C., Fichaut, M., Balopoulos, E., Iona, S., Dooley, H., Garcia, M. J., Manca, B., Giorgetti, A., Manzella, G., Mikhailov, N., Pinardi, N., and Zavatarelli, M.: The Western Mediterranean Deep Water: A proxy for climate change, Geophys. Res. Lett., 32, 1-4, doi:10.1029/2005GL022702, 2005.

Roether, W., Manca, B. B., Klein, B., Bregant, D., Georgopoulos, D., Beitzel, V., Kovacevic, V., and Luchetta, A.: Recent Changes in Eastern Mediterranean Deep Waters, Science, 271, 333-335, doi:10.1126/science.271.5247.333, 1996.

Roether, W., Klein, B., Manca, B. B., Theocharis, A., and Kioroglou, S.: Transient Eastern Mediterranean deep waters in response to the massive dense-water output of the Aegean Sea in the 1990s, Prog. Oceanogr., 74, 540-571, doi:10.1016/j.pocean.2007.03.001, 2007.

Roether, W., Jean-Baptiste, P., Fourré, E., and Sültenfuß, J.: The transient distributions of nuclear weapon-generated tritium and its decay product ${ }^{3} \mathrm{He}$ in the Mediterranean Sea, 1952-2011, and their oceanographic potential, Ocean Science, 9, 837-854, doi:10.5194/os-9-837-2013, 2013.

Roether, W., Klein, B., and Hainbucher, D.: The Eastern Mediterranean Transient: Evidence for Similar, Am. Geophys. Un., 12, 75-83, 2014.

Rousseau, T. C. C., Sonke, J. E., Chmeleff, J., van Beek, P., Souhaut, M., Boaventura, G., Seyler, P., and Jeandel, C.: Rapid neodymium release to marine waters from lithogenic sediments in the Amazon estuary, Nat. Commun., 6, 7592, doi:10.1038/ncomms8592, 2015.

Samuel, S., Haines, K., Josey, S., and Myers, P. G.: Response of the Mediterranean Sea thermohaline circulation to observed changes in the winter wind stress field in the period 1980-1993, J. Geophys. Res., 104, 7771, doi:10.1029/1998JC900130, 1999.

Scheuvens, D., Schutz, L., Kandler, K., Ebert, M., and Weinbruch, S.: Bulk composition of northern African dust and its source sediments - A compilation, Earth-Sci. Rev., 116, 170194, doi:10.1016/j.earscirev.2012.08.005, 2013.

Schijf, J., de Baar, H. J., Wijbrans, J. R., and Landing, W. M.: Dissolved rare earth elements in the Black Sea, Deep Sea Res. Pt. I, 38, S805-S823, doi:10.1016/S0198-0149(10)80010-X, 1991.

Siddall, M., Khatiwala, S., van de Flierdt, T., Jones, K., Goldstein, S. L., Hemming, S., and Anderson, R. F.: Towards explaining the $\mathrm{Nd}$ paradox using reversible scavenging in an ocean general circulation model, Earth Planet. Sc. Lett., 274, 448-461, doi:10.1016/j.epsl.2008.07.044, 2008.

Spivack, A. J. and Wasserburg, G.: Neodymium isotopic composition of the Mediterranean outflow and the eastern North Atlantic, Geochim. Cosmochim. Ac., 52, 2767-2773, doi:10.1016/00167037(88)90144-5, 1988.
Stanev, E. V. and Peneva, E. L.: Regional sea level response to global climatic change: Black Sea examples, Europe, 32, 33-47, 2002.

Stichel, T., Frank, M., Rickli, J. D., Hathorne, E., Haley, B. A., Jeandel, C., and Pradoux, C.: Hafnium and neodymium in surface waters of the Atlantic sector of the Southern Ocean, Earth Planet. Sc. Lett., 317-318, 282-294, 2012.

Tachikawa, K., Jeandel, C., and Roy-Barman, M.: A new approach to the Nd residence time in the ocean: the role of atmospheric inputs, Earth Planet. Sc. Lett., 170, 433-446, doi:10.1016/S0012821X(99)00127-2, 1999.

Tachikawa, K., Athias, V., and Jeandel, C.: Neodymium budget in the modern ocean and paleo-oceanographic implications, J. Geophys. Res., 108, 3254, doi:10.1029/1999JC000285, 2003.

Tachikawa, K., Roy-Barman, M., Michard, A., Thouron, D., Yeghicheyan, D., and Jeandel, C.: Neodymium isotopes in the Mediterranean Sea: Comparison between seawater and sediment signals, Geochim. Cosmochim. Ac, 68, 3095-3106, doi:10.1016/j.gca.2004.01.024, 2004.

Theocharis, A. and Kontoyiannis, H.: Interannual variability of the circulation and hydrography in the Eastern Mediterranean (1986-1995), in: NATO Science Series, Environmental Security: The Eastern Mediterranean as a Laboratory Basin for the As, edited by: Malanotte-Rizzoli, P. and Eremeev, V. N., Kluwer Academic Publishing, Dordrecht, the Netherlands, 453-464, 1999.

Theocharis, A., Georgopoulos, D., Karagevrekis, P., Iona, A., Perivoliotis, L., and Charalambidis, N.: Aegean influence in the deep layers of the Eastern Ionian Sea, Rapport de la Commission international pour l'Exploration Scientifique de la Mer Méditerranée, 33, 235, 1992.

Theocharis, A., Nittis, K., Kontoyiannis, H., Papageorgiou, E., and Balopoulos, E.: Climatic changes in the Aegean Sea influence the Eastern Mediterranean thermohaline circulation (1986-1997), Geophys. Res. Lett., 26, 1617-1620, 1999.

Tranchida, G., Oliveri, E., Angelone, M., Bellanca, A., Censi, P., D'Elia, M., Neri, R., Placenti, F., Sprovieri, M., and Mazzola, S.: Distribution of rare earth elements in marine sediments from the Strait of Sicily (western Mediterranean Sea): Evidence of phosphogypsum waste contamination, Mar. Pollut. Bull., 62, 182191, doi:10.1016/j.marpolbul.2010.11.003, 2011.

Vance, D., Scrivner, A. E., Beney, P., Staubwasser, M., Henderson, G. M., and Slowey, N. C.: The use of foraminifera as a record of the past neodymium isotope composition of seawater, Paleoceanography, 19, PA2009, doi:10.1029/2003PA000957, 2004.

Wilson, D. J., Piotrowski, A. M., Galy, A., and McCave, I. N.: A boundary exchange influence on deglacial neodymium isotope records from the deep western Indian Ocean, Earth Planet. Sc. Lett., 341-344, 35-47, doi:10.1016/j.eps1.2012.06.009, 2012.

Zervakis, V., Georgopoulos, D., and Drakopoulos, P. G.: The role of the North Aegean in triggering the recent Eastern Mediterranean climatic changes, J. Geophys. Res., 105, 26103-26116, 2000. 